
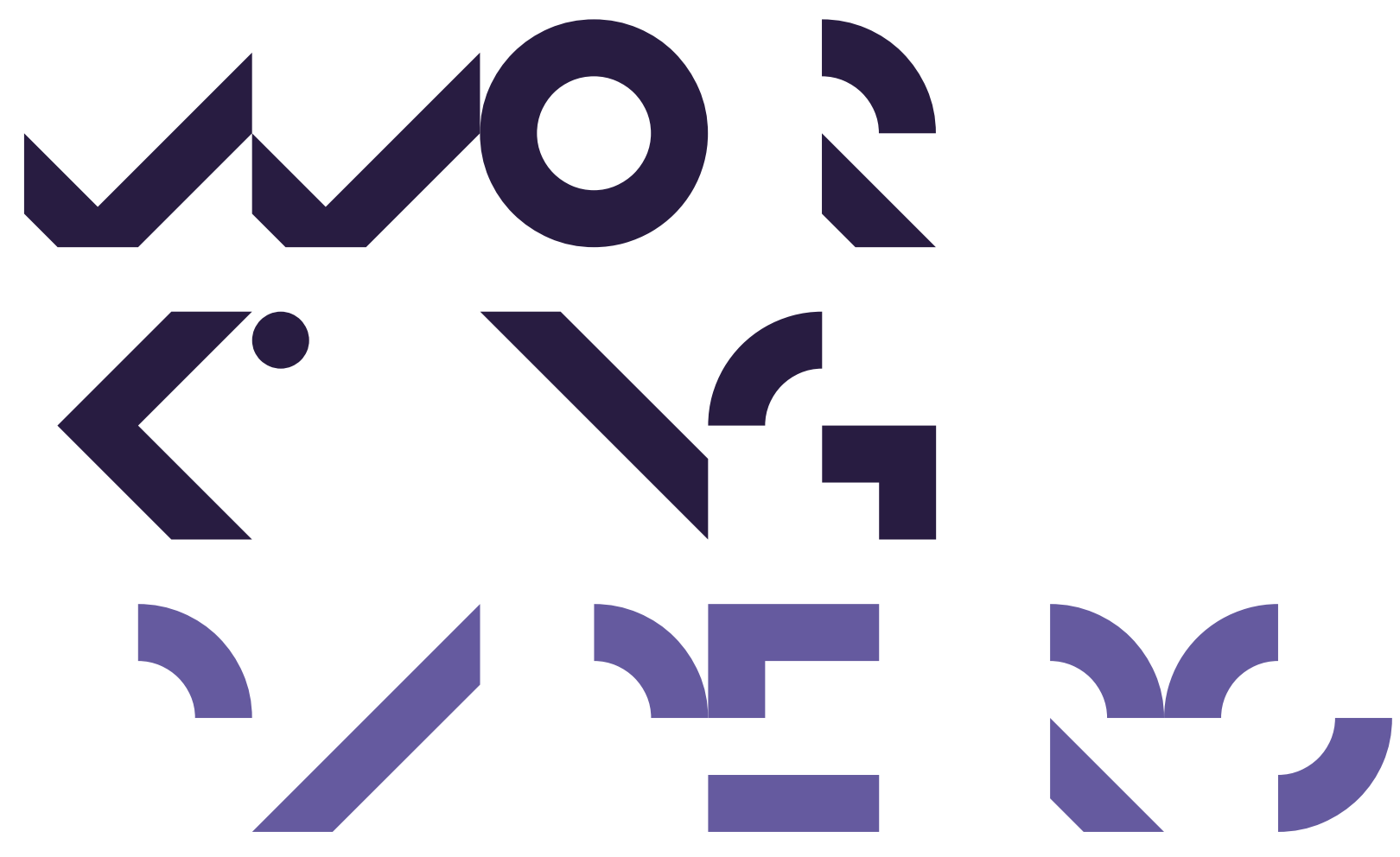

Economics Working Papers

2013-20

Import-push or Export-pull?

An Industry-level Analysis of the Impact of Trade on Firm Exit

Ina Charlotte Jäkel 


\section{Import-push or Export-pull? \\ An Industry-level Analysis of the Impact of Trade on Firm Exit}

Ina Charlotte Jäkel*

Abstract. Does the selection effect of trade work solely through competition from imports, or does the export market further contribute to firm selection? This paper provides a re-interpretation of the different mechanisms in terms of selection on profitability - rather than productivity - and derives novel predictions regarding the export market and the role of product differentiation. Empirical results for a sample of Danish manufacturing industries confirm the import- "push" hypothesis as well as the export-"pull" hypothesis, but also reveal differences across industries. The selection effect of trade is mainly driven by the "import-push" if product differentiation is high, whereas it is driven by the "export-pull" if goods are homogeneous.

Keywords: Firm exit · Exports · Import competition · Heterogeneous firms

JEL classification: $\quad \mathrm{F} 12 \cdot \mathrm{F} 15 \cdot \mathrm{D} 21$

\section{Introduction}

Trade theory points to the welfare gains from trade through within-industry reallocations: trade openness allows the most productive firms to expand their market shares and forces the least productive ones to exit. In the public debate, on the other hand, concerns about the displacement of workers and the crowding out of local varieties prevail, and both of these effects are strongly connected to the notion of firms being squeezed out of the domestic market. Trade exposure and its effect on firm survival therefore have wide implications for both national welfare and public support for free trade.

This paper has benefited from the useful comments of two anonymous referees. A revised version is forthcoming in Empirica. Journal of European Economics. I am grateful to Ingo Geishecker, Sourafel Girma, Dimitra Petropoulou, Hans-Jörg Schmerer, Philipp Schröder, Valdemar Smith and Allan Sørensen for helpful comments and suggestions. Thanks are also due to seminar and conference participants at universities in Aarhus, Göttingen and Stockholm as well as at the Leverhulme Center for Research on Globalisation and Economic Policy and ZEW Mannheim. Financial support from the Tuborg Foundation is gratefully acknowledged.

*Department of Economics and Business, Aarhus University, Fuglesangs Allé 4, 8210 Aarhus V, Denmark. E-mail: InaJ@asb.dk, Tel.: +45 871 65195, Fax: +45 87150201. 
The seminal papers of Melitz (2003) and Melitz \& Ottaviano (2008) are ambiguous on the precise mechanisms at hand, presenting two conflicting hypotheses. The import- "push" hypothesis postulates that increased competition from foreign firms squeezes domestic firms out of the market. The export-"pull" hypothesis, on the contrary, conjectures that high productivity firms expand their market shares and use of resources at the expense of low-productivity firms, which are forced to exit. In Melitz (2003), Melitz \& Ottaviano (2008) and related papers, selection is on productivity. However, ultimately selection is on profitability and empirically the demand side is more important than productivity in shaping the survival prospects of a firm; see Foster et al. (2008). An increase in exporting opportunities can under these premises lead to a fall in firm failure, namely by increasing profitability. This last channel is unforeseen in models where productivity is the key variable.

Given these theoretical ambiguities, the present paper first discusses the different mechanisms trough which trade exposure on both import and export markets affects firm profitability, and hence survival. We then provide an empirical analysis based on data for a sample of 31 Danish manufacturing industries over the period 2001 to 2007.

Our exposition reveals that product differentiation has an ambiguous role in altering the impact of import exposure. Product differentiation shields firms from international competition. At the same token, in differentiated industries within-industry productivity differences are not reflected in large differences in profits. Indeed, the data show that differentiated industries are characterized by lower degrees of concentration and a higher share of small firms. Empirical results confirm that, on average, import competition crowds out domestic firms. Furthermore, this effect is robustly larger if product substitutability is low. This latter finding contrasts the common wisdom that product differentiation diminishes the pro-competitive impact of trade, but it seems consistent with inter-industry differences in market structure.

Due to a high degree of correlation, identification of the joint impact of import and export openness is exacerbated when the latter is measured by an industry's export intensity. As a remedy, we propose to use export penetration of the foreign market as a theory-consistent measure of export openness, which conveniently bypasses the multicollinearity issue. This measure of export exposure is closely linked to the relative competitiveness of domestic producers compared to foreign producers. Indirectly, it also reflects foreign demand for an industry's output, and therefore export potential. Empirical results confirm the export- "pull" hypothesis, but only for industries where product differentiation is low. In contrast - and in line with the postulated link between exporting opportunities, profitability and firm survival - we find a weakly negative effect of export openness if product differentiation is sufficiently high. 
The present paper is related to a rich empirical literature on the selection effect of trade, which focuses predominantly on imports; see inter alia Bernard et al. (2006), Coucke \& Sleuwaegen (2008), Greenaway et al. (2008) and Gu et al. (2003). The implicit assumption here is either that only import competition has an effect on firm failure, or that bilateral trade costs are symmetric. Apparently, such an identification strategy does not take into account $(i)$ potential asymmetries in the implications of import and export openness, and (ii) industry-level trade imbalances. Regarding the exporting side of the economy, empirical studies have focused on the exporting status of the firm, showing that exporting firms are more likely to survive (Bernard \& Jensen, 2007; Harris \& Li, 2010; Baldwin \& Yan, 2011). But the export- "pull" effect is related to the industry's - rather than the firm's - export activities.

Evidence on the differential impact of export vs. import openness is scarce and studies that look at one particular type of impediment to trade, namely tariffs, report diverging results; see Head \& Ries (1999) and Baggs (2005). Closest in spirit to our study, Colantone \& Sleuwaegen (2010) consider the differential impact of import and export exposure on firm entry and exit. Based on a sample of twelve manufacturing industries across eight European countries, they find that only import competition matters for firm failure. ${ }^{1}$ Our results advance on their findings, since our empirical approach facilitates the identification of the distinct impact of export exposure.

We contribute to the empirical literature by $(i)$ considering the role of product differentiation; ( $i i)$ proposing a novel measure of export openness which allows us to identify its independent contribution; and (iii) establishing a causal link between trade exposure and firm exit by using instrumental variable techniques. Moreover, we focus on a small open economy where trade activities are expected to be more important in shaping firm survival.

The next section discusses our novel predictions regarding the impact of trade on firm exit when selection is on profitability. Section 3 presents the data and outlines the econometric approach. Estimation results are reported in section 4 . The last section concludes.

\section{Predictions on trade-induced firm failure}

This section presents novel predictions regarding the impact of trade exposure on firm exit. For conciseness, we frame our analysis in terms of the partial-equilibrium setting in Chaney (2008), who extends the Melitz (2003) model to a multi-country set-up with asymmetric countries and trade costs.

\footnotetext{
${ }^{1}$ Emami Namini et al. (2011) also find evidence of export-induced factor market competition, but do not consider the differential role of export and import openness.
} 


\subsection{Conceptual framework}

In Melitz (2003) productivity differences perfectly predict profitability differences across firms and firm exit is driven by movements in the threshold productivity for survival and a per-period probability of exit that is constant across firms. Foster et al. (2008), however, point out that selection on profitability and productivity are not synonymous due to the presence of other idiosyncratic factors besides productivity, notably firm-specific demand shocks. And even demand shocks that are common across firms can break the symmetry between selection on profitability and productivity. Exporting opportunities can be seen as such a positive demand shock, enhancing the chances of survival. Focusing on firm profitability is thus more general: in particular, a given firm's probability of failure can either increase or fall, dependent on the direction of change in profits. Under selection on productivity, in contrast, a firm's probability of exit potentially increases - but never falls - due to trade liberalization.

We therefore depart from the literature by assuming that firm exit depends on profitability. ${ }^{2}$ Profits of firm $k, \pi(k)$, are determined by the productivity of the firm, $\varphi_{k}$, and a set of factors external to the firm, such as trade costs. In the open economy, profits can be decomposed into domestic profits $\pi_{i i}$ and exporting profits $\sum_{\ell \neq i} \pi_{i \ell}$. Denoting the per-period exit probability of firm $k$ by $\delta_{k}$,

$$
\delta_{k}=\delta[\pi(k)]=\delta\left[\pi_{i i}\left(\varphi_{k}, \cdot\right)+\sum_{\ell \neq i} \pi_{i \ell}\left(\varphi_{k}, \cdot\right)\right] ; \quad \delta_{k} \in[0 ; 1] .
$$

Aggregate firm failure is then given by $\widetilde{\delta} M$, where $\widetilde{\delta} \equiv E[\delta]$ is the average industry-wide exit probability and $M$ is the number of firms. Our specification for $\delta_{k}$ does not place any restrictions on functional form. In particular, we do not impose $\widetilde{\delta}=\delta(\widetilde{\pi})$, i.e. the expected probability of firm failure need not be equal to the probability of exit of the firm with average profits. As a result, when a given shock affects the profitability of some firms positively and of other firms negatively, the change in $\widetilde{\delta}$ and hence aggregate firm failure will in general be ambiguous. This flexibility allows us to make very general predictions on trade-induced firm failure.

Notably, according to equation (1) a firm may exit even though it makes positive profits. If there is a one-time start-up cost for market entry which is recoverable, then being active has an opportunity cost; see Hopenhayn (1992); Ericson \& Pakes (1995). In large economies, relatively few firms are engaged in exporting activities, leaving limited room for the export market to affect

\footnotetext{
${ }^{2}$ Pflüger \& Russek (2011) and Felbermayr \& Spiegel (2012) introduce firm heterogeneity in the probability of exit into the Melitz (2003) framework. In Pflüger \& Russek (2011), firms are heterogeneous in productivity and exit probabilities are inversely related to firm productivity. To the contrary, in Felbermayr \& Spiegel (2012) firms differ only in their per period exit probability. In both papers, firm-specific exit probabilities are therefore entirely determined by exogenous factors. In Schröder \& Sørensen (2012), exogenous technological progress generates endogenous exit decisions of firms. To the contrary, we highlight how a firm's probability of exit evolves over time as profits change.
} 
firm survival. The small open economy case, to the contrary provides a highly suitable setting for investigating export-market related effects on firm exit. In particular, while aggregate Danish exports are dominated by a few large exporters, this concentration is much lower than in countries with a large domestic market such as the US; see Eriksson et al. (2009).

Exporting from country $i$ to country $j$ is subject to two types of trade costs: variable trade costs $\tau_{i j}$ and a per-period fixed cost of exporting $f_{i j}$. Preferences are given by the CES utility function. The demand for a variety produced by firm $k$ sold in country $j$ is given by $q_{i j}(k)=Y_{j} p_{i j}(k)^{-\sigma} / P_{j}^{1-\sigma}$ with price $p_{i j}(k)=\frac{\sigma}{\sigma-1} \frac{\tau_{i j} w_{i}}{\varphi_{k}}$, where $P_{j}$ and $Y_{j}$ are the price index and income in country $j$ respectively, $\sigma$ is the elasticity of substitution between varieties and $w_{i}$ is the unit cost of labor in the home country. Assuming $\tau_{i i}=1$ and $f_{i i}=0$, we have ${ }^{3}$

$$
\pi_{i i}(k)=\mu Y_{j}\left(\frac{w_{i}}{\varphi_{k} P_{i}}\right)^{1-\sigma} \quad \text { and } \quad \pi_{i j}(k)=\mu Y_{j}\left(\frac{\tau_{i j} w_{i}}{\varphi_{k} P_{j}}\right)^{1-\sigma}-f_{i j} .
$$

where $\mu \equiv \frac{(\sigma-1)^{\sigma-1}}{\sigma^{\sigma}}$. Only a firm with productivity $\varphi_{k} \geq \bar{\varphi}$ exports, where $\bar{\varphi}$ satisfies:

$$
\pi_{i j}(\bar{\varphi})=0 \Leftrightarrow \bar{\varphi}=\left(\frac{f_{i j}}{Y_{j} \mu}\right)^{1 /(\sigma-1)} \frac{\tau_{i j} w_{i}}{P_{j}} .
$$

Denoting $\Omega_{\ell}$ as the mass of varieties supplied by country $\ell$, the domestic price index is given by

$$
P_{i}=\left[\sum_{\ell} \sum_{k \in \Omega_{\ell}} p_{\ell i}(k)^{1-\sigma} d k\right]^{\frac{1}{(1-\sigma)}}
$$

\subsection{Import-"push", export-"pull" and exporting opportunities}

With CES preferences, firms charge a constant mark-up over marginal costs and import penetration therefore does not have any pro-competitive effects in the sense of reducing market power for incumbents. Still, import competition - driven by the cost variables for foreign firms $\tau_{j i}, f_{j i}$ and $w_{j}-$ affects profits of domestic firms indirectly, via the domestic price index: as foreign costs fall, foreign competitors are able to lower their prices and additionally more firms enter the domestic market. This tends to decrease the domestic price index, and thereby toughens competition. Profit opportunities for all domestic firms fall, negatively affecting their survival probability.

Prediction 1. Competition from imports raises the average industry-wide probability of exit, $\widetilde{\delta}$.

With CES demand, import competition leads to a proportional loss in market shares for all firms, and therefore yields an extenuated import-"push". This differs from the Melitz \& Ottaviano (2008)

\footnotetext{
${ }^{3}$ With $f_{i i}>0$, setting $\pi_{i i}(k)$ equal to zero would imply a zero profit cut-off for domestic production. Opportunity costs to remaining active, which are implicit in our specification for exit, are however theoretically equivalent to fixed per period production costs (Hopenhayn, 1992). Letting $f_{i i}>0$, the firm-specific exit probability in (1) could similarly be motivated by introducing heterogeneity in fixed costs.
} 
set-up with a linear demand system and endogenous mark-ups, where import competition has a larger impact on high-price (low-productivity) firms compared to low-price (high-productivity) firms. Despite these differences, qualitative results on $\widetilde{\delta}$ are identical in both frameworks.

Export openness is driven by falling trade costs for domestic firms $\left(\tau_{i j}\right.$ and $\left.f_{i j}\right)$ and rising foreign demand, $Y_{j}$. In particular, $Y_{j}$ can be seen as a demand shifter. For a small open economy, the impact of domestic firms on the foreign price index is negligible. ${ }^{4}$

In a first step we make the simplifying assumption that labor supply is perfectly elastic and domestic wages $w_{i}$ are exogenously fixed. ${ }^{5}$ Given an increase in export openness, exporters can increase their profits on export markets. Moreover, the productivity threshold for exporting decreases and thus more firms enter the export market. For these old and new exporters, the probability of exit falls. Being able to enter an additional market is similar to an outward shift in the firm's demand curve. Finally, firms that remain non-exporters are unaffected.

Prediction 2a. If labor supply is perfectly elastic, the average industry-wide probability of exit, $\widetilde{\delta}$, falls in response to an increase in export openness.

If firms compete for a limited pool of workers, job expansion at exporters puts upward pressure on industry-level wages. Assume that exporting profits still depend positively on export openness. Domestic profits of all firms are now negatively affected by increasing export openness. Non-exporting firms suffer a profit loss. Similarly, for small exporters the loss in domestic profits exceeds the gain in exporting profits, and thus their profits fall as well. Only sufficiently large exporters, for which the share of exporting profits in aggregate profits is high, gain from increasing export openness. The change in the industry-wide probability of exit is therefore ambiguous: $\delta_{k}$ increases for some firms but decreases for others.

Prediction 2b. Assume that export openness bids up an industry's wage rate. The average industrywide probability of exit increases in response to an increase in export openness if and only if the export- "pull" dominates the effect of increased profit opportunities.

\subsection{The role of product differentiation}

Product differentiation, captured by $\sigma$, modifies the impact of import openness through at least three channels. First, if product differentiation is high, consumers care for variety and a given firm's

\footnotetext{
${ }^{4}$ If domestic export behavior affected the foreign price index, falling trade costs for domestic exporters would tend to increase competition in the export market. We ignore such indirect effects, working via $P_{j}$, in our discussion.

${ }^{5}$ This is the implicit hypothesis in Melitz \& Ottaviano (2008). From an empirical perspective, expansion of exporting firms leaves wages unaffected if industry employment increases correspondingly, e.g. through a fall in unemployment.
} 
demand is less responsive to the prices of other firms. This tends to attenuate the impact of import competition. Second, however, new imported varieties have a substantial impact on the domestic price index only if $\sigma$ is small; see Broda \& Weinstein (2006). ${ }^{6}$ And third, if products are highly differentiated price competition is lower in the sense that market shares are less responsive to own price. As a result, productivity differences between firms are not mirrored in large differences in profits. Hence, product differentiation also affects market structure and the size distribution of firms. ${ }^{7}$ Below, we provide some empirical evidence that highly differentiated industries are on average characterized by lower degrees of concentration and a larger share of small firms. The share of firms that are vulnerable to import competition therefore tends to be higher. The second and third channel amplify the impact of import competition.

Prediction 3. Competition from imports always increases the average industry-wide probability of exit. The effect may however be higher or lower in differentiated industries.

In order to highlight the independent contributions of profit opportunities and the export- "pull", we again first consider the case of perfectly elastic labor supply. As noted in Chaney (2008), a higher elasticity of substitution dampens the responsiveness of the extensive margin of trade - exports by new exporters - with respect to changes in trade costs. Since competition is fierce, profit opportunities are low and market entry is not very attractive. Moreover, a higher elasticity of substitution magnifies the responsiveness of the intensive margin - exports by existing exporters - to changes in export openness. The intuition is that, if goods are substitutable, small changes in the price lead to big shifts in demand, and thus sales and profits.

Assume that changes in profits matter more for small firms. ${ }^{8}$ Under this assumption, export market entry is more crucial for firm survival because it increases profits of the relatively small firms. A high degree of differentiation then amplifies the reduction in the average probability of exit due to an increase in export openness.

Prediction 4a. Let labor supply be perfectly elastic. Then, the reduction in the average industry-wide probability of exit due to export openness is the higher, the higher the degree of product differentiation.

\footnotetext{
${ }^{6}$ Moreover, if $\sigma$ is small changes in foreign cost variables have a higher impact on the number of imported varieties; see the discussion below.

${ }^{7}$ The elasticity of substitution reflects the toughness of competition in the sense that competition increases the profits of a more efficient firm, relative to a less efficient firm; see Boone (2008). Sutton (2007) reviews the literature on the determinants of market structure and highlights the paradoxical result that an increase in competition may actually induce an increase in concentration. Product differentiation may reduce industry concentration also because market entry is easier; see Guth (1971).

${ }^{8}$ If there is a minimum level of profits that needs to be obtained in order to make operating attractive, given a change in profits smaller firms are more likely to fall below this minimum threshold.
} 
Finally, we also factor in the export-"pull". Combining prediction $2 \mathrm{~b}$ with the intuition behind prediction $4 \mathrm{a}$, we conclude with the following prediction.

Prediction 4b. Assume that export openness bids up an industry's wage rate. Then, any potential increase in the average industry-wide probability of exit due to the "export-pull" is mitigated by the beneficial impact of exporting opportunities if product differentiation is high.

\section{Empirical approach}

\section{$3.1 \quad$ Measuring trade openness}

Instead of observing the driving forces of the import- "push" and export-"pull" directly, we exploit the fact that measures of trade openness are indicators of underlying trade costs. In particular, as in Chaney (2008) we assume that the distribution of productivities is Pareto with parameter $\gamma$ and take a short-run perspective in that the mass of potential entrants is exogenously fixed and proportional to a country's effective size $w_{i} L_{i}$, where $L_{i}$ is country size. ${ }^{9}$ We also define a measure of the overall restrictiveness of trade as $\kappa_{i j}=\left(w_{i} \tau_{i j}\right)^{-\gamma} f_{i j}^{1-\gamma /(\sigma-1)}$.

Denote aggregate supply from country $\ell$ to $i$ by $X_{\ell i}$. Import penetration is given by the market share of foreign firms on the domestic market,

$$
\operatorname{Imp} \equiv \frac{\sum_{\ell \neq i} X_{\ell i}}{\sum_{\ell} X_{\ell i}}=\frac{\sum_{\ell \neq i}\left(w_{\ell} L_{\ell}\right) \kappa_{\ell i}}{\sum_{\ell}\left(w_{\ell} L_{\ell}\right) \kappa_{\ell i}}=\left(1+\frac{\left(w_{i} L_{i}\right) \kappa_{i i}}{\sum_{\ell \neq i}\left(w_{\ell} L_{\ell}\right) \kappa_{\ell i}}\right)^{-1} .
$$

Imp depends positively on the weighted average trade cost of exporting to the domestic market for foreign firms relative to the costs of supplying the domestic market for domestic firms, where weights are given by the mass of potential entrants in country $\ell, w_{\ell} L_{\ell}$. It therefore gives a comprehensive measure of import competition.

Regarding the export market, we first define the export intensity as the share of exports in overall sales

$$
\operatorname{Exp}^{(1)} \equiv \frac{\sum_{\ell \neq i} X_{i \ell}}{\sum_{\ell} X_{i \ell}}=\frac{\sum_{\ell \neq i} \Theta_{\ell} \kappa_{i \ell}}{\sum_{\ell} \Theta_{\ell} \kappa_{i \ell}}=\left(1+\frac{\Theta_{i} \kappa_{i i}}{\sum_{\ell \neq i} \Theta_{\ell} \kappa_{i \ell}}\right)^{-1}
$$

where $\Theta_{\ell} \equiv P_{\ell}^{\gamma} Y_{\ell}^{\gamma /(\sigma-1)}$. Due to our small-economy assumption ( $\kappa_{i \ell}$ does not affect the foreign price level $P_{\ell}$ ), a fall in domestic composite trade costs relative to the cost of supplying the domestic market is reflected in an increase in the export intensity. $\operatorname{Exp}^{(1)}$ is a very crude measure of the underlying economic forces of exporting opportunities or the export-"pull", since it reflects exporting relative to domestic profit opportunities. In small open economies, the export intensity as given in (6) may

\footnotetext{
${ }^{9}$ Our formulations differ slightly from Chaney (2008), since we do not impose global equilibrium.
} 
still be informative for testing our hypotheses on the role of export openness. On the contrary, if the domestic market is large, (6) has little informational value.

Analogous to (5), the domestic market share on world markets, $\left(\sum_{\ell \neq i} X_{i \ell}\right) /\left(\sum_{\ell \neq i} \sum_{m} X_{m \ell}\right)$ is a theory-consistent measure of export exposure. In particular, foreign demand is in the denominator, reflecting export potential. Due to lack of data on foreign aggregate demand or production for all $\ell \neq i$, our second measure of export openness is given by exports from $i$ to $j$ relative to production in $j$, where the export market may include several countries:

$$
\operatorname{Exp}^{(2)} \equiv \frac{X_{i j}}{X_{i j}+X_{j j}+\sum_{\ell} X_{j \ell}}=\frac{w_{i} L_{i} \Theta_{j} \kappa_{i j}}{\left(w_{i} L_{i} \Theta_{j}\right) \kappa_{i j}+\left(w_{j} L_{j} \Theta_{j}\right) \kappa_{j j}+\sum_{\ell}\left(w_{j} L_{j} \Theta_{\ell}\right) \kappa_{j \ell}}
$$

This measure is convenient in that it requires production data only for a subset of destination countries. If countries in market $j$ trade only with each other, equation (7) reduces to $i$ 's market share

in $j, \frac{\left(w_{i} L_{i}\right) \kappa_{i j}}{\left(w_{i} L_{i}\right) \kappa_{i j}+\left(w_{j} L_{j}\right) \kappa_{j j}} . \operatorname{Exp}^{(2)}$ is increasing in the cost of exporting to market $j$ for domestic firms, relative to the costs of supplying $j$ for firms in $j$. It therefore reflects the relative competitiveness of firms from $i$ in market $j$. Moreover, its denominator is, via the goods market equilibrium, also linked to foreign demand and therefore to export opportunities.

\subsection{Data}

In the empirical analysis we use Danish industry-level data from the Business Demography and the VAT Statistics, provided by Statistics Denmark. The Business Demography statistics are based on the Central Business Register which covers all real active enterprises, i.e. those with a workload of at least 0.5 man-years. Enterprises which only some years after registration get real activity are therefore defined as new enterprises. The VAT statistics include all enterprises for which the yearly turnover is expected to exceed DKK $20000(\approx$ EUR 3000). They are collected on a monthly basis, such that yearly aggregates correspond to the calendar year, rather than the fiscal year. The reference period is therefore the same for both data sources. The data are at the level of the 111-grouping of the Danish industry code and contain information on 31 manufacturing industries for the period 2001-2007. The 111-grouping is part of the "Standard industrial groupings for publishing purposes" of Statistics Denmark. At this level of aggregation, there are 36 manufacturing industries. Five industries had to be excluded due to insufficient information; see table A.1 in the appendix.

\subsubsection{Firm exit}

In the Business Demography statistics, exits are defined as enterprises which had real activity in the previous year but which did not survive until the present year. Enterprises which cease to exist 
Figure 1: Exit rates and trade exposure, 2000-2007ª
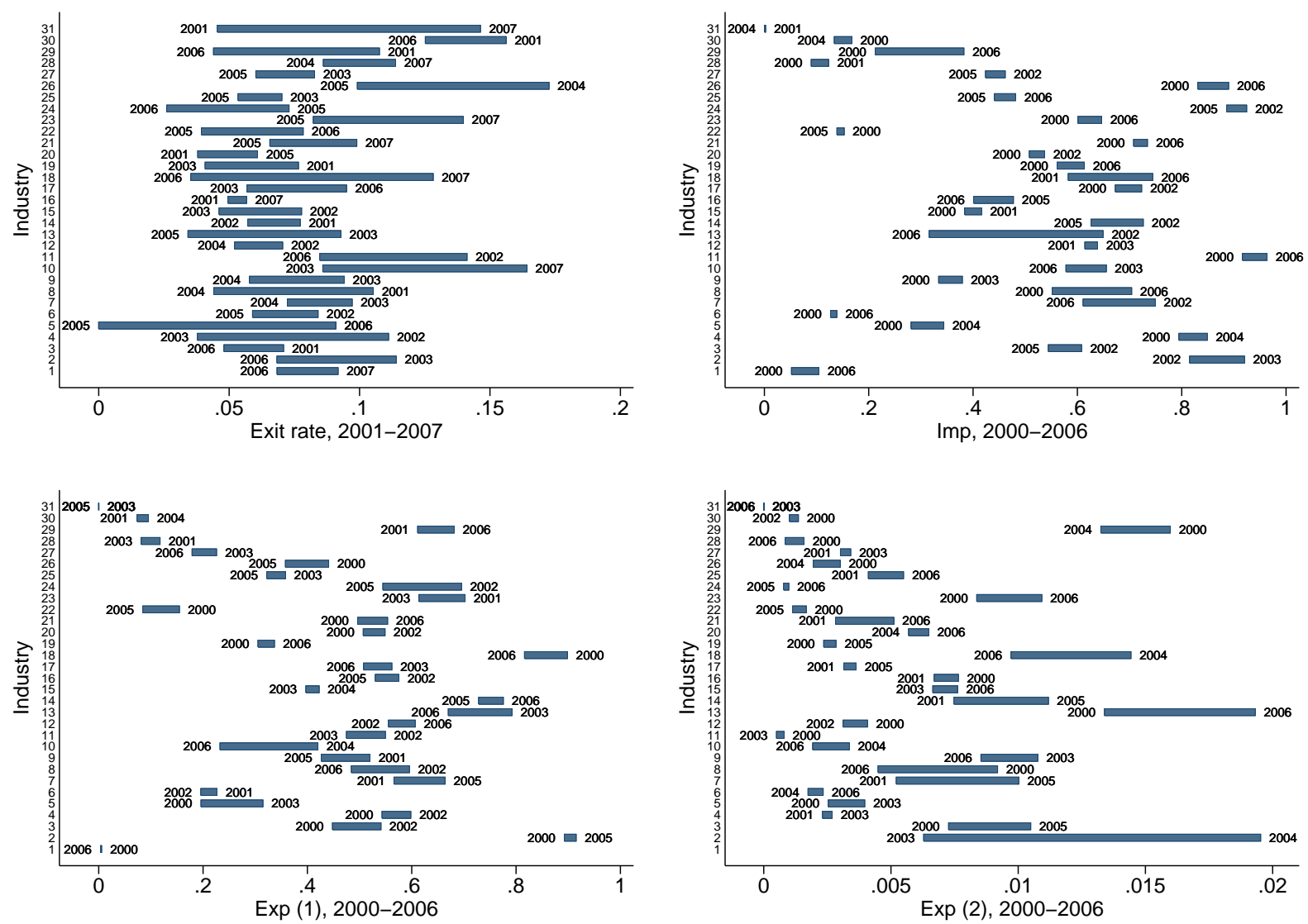

${ }^{a}$ Industries: 1 Bakers shops, 2 Building of ships and boats, 3 Mfr. of agricultural machinery, 4 Mfr. of basic metals, 5 Mfr. of beverages, 6 Mfr. of building materials of metal, $7 \mathrm{Mfr}$. of computers and electric motors, $8 \mathrm{Mfr}$. of domestic appliances, 9 Mfr. of furniture, $10 \mathrm{Mfr}$. of glass and ceramic goods, $11 \mathrm{Mfr}$. of leather and footwear, $12 \mathrm{Mfr}$. of machinery for industries, $13 \mathrm{Mfr}$. of marine engines, compressors, $14 \mathrm{Mfr}$. of medical equipment optical instruments, $15 \mathrm{Mfr}$. of other food products, $16 \mathrm{Mfr}$. of ovens and cold-storage plants, $17 \mathrm{Mfr}$. of paints and soap, $18 \mathrm{Mfr}$. of pharmaceuticals, $19 \mathrm{Mfr}$. of pulp, paper and paper products, $20 \mathrm{Mfr}$. of rubber and plastic products, $21 \mathrm{Mfr}$. of textiles, $22 \mathrm{Mfr}$. of tiles bricks, cement and concrete, $23 \mathrm{Mfr}$. of toys and jewelery, $24 \mathrm{Mfr}$. of transport equipment, excl. ships, $25 \mathrm{Mfr}$. of various metal products, $26 \mathrm{Mfr}$. of wearing apparel, $27 \mathrm{Mfr}$. of wood and wood products, 28 Printing activities, 29 Production etc. of meat and meat products, 30 Publishing activities, excluding newspapers, 31 Publishing of newspapers.

because of a merger or a change in their registration number are not included in the exit figures. ${ }^{10}$

The data thus reflect firm failure in the sense of a previously active firm becoming inactive. The upper left-hand graph in figure 1 summarizes the variation in exit rates - the number of firm exits between $t$ and $t-1$ relative to the number of firms in $t-1$ - across industries and time. Each bar gives the range of the exit rate observed during the sample period for a specific industry. To the left and the right of the bars, we report the year with the lowest (highest) exit rate in the respective industry. Average exit rates vary considerably across industries, between $4.9 \%$ in Manufacturing of Beverages and $14.2 \%$ in Publishing activities, excl. newspapers. Similarly, most industries exhibit substantial variation over time and exit rates have fallen for some industries but increased for others.

\footnotetext{
${ }^{10}$ Note that the industry and firm characteristics shaping firm exit by merger/acquisition or industry switching may differ from those determining exit via close-down; see Bernard et al. (2006) and Greenaway et al. (2008).
} 


\subsubsection{Trade data}

We combine the data on firm demographics with product-level data on imports from Eurostat's COMEXT database. A correspondence table links each product in the 8-digit CN code to a specific industry. We also employ industry-level data from the VAT statistics, which contain information on domestic sales and exports for each industry.

Imports, $\sum_{\ell \neq i} X_{\ell i}$, are computed as the sum over all products in an industry and all trading partners. Given information on domestic sales of Danish firms, we can then construct $\operatorname{Imp} \equiv \frac{\sum_{\ell \neq i} X_{\ell i}}{\sum_{\ell} X_{\ell i}}$. Next, based on the VAT statistics we compute a measure of the industry-level export intensity as in equation (6), where $\sum_{\ell \neq i} X_{i \ell}$ are Danish exports to all trading partners in a given industry and overall sales of domestic firms $\sum_{\ell} X_{i \ell}$ are in the denominator. ${ }^{11}$ Furthermore, we measure domestic penetration of the foreign market as in equation (7), where $j$ is equal to the EU 24 (i.e. the EU 25 excluding Denmark). Data on European production for each of the 24 countries is available from Eurostat's Structural Business Statistics database and is coded according to Nace Rev. 1.1, which can be linked to the Danish industry code. The numerator of $\operatorname{Exp}^{(2)}$ is given by Danish exports to the EU $24,{ }^{12}$ whereas the denominator is the sum of Danish exports and aggregate EU 24 production. Intra-European trade constitutes a large share of overall external trade for most European countries, including Denmark. In consequence, $\operatorname{Exp}^{(2)}$ is a good measure of export potential and the relative competitiveness of Danish firms on export markets.

As documented in figure 1, trade openness differs significantly across industries, but also across openness measures. For example, on average 94\% (86\%) of domestic consumption of Leather and Footwear (Wearing Apparel) is imported, whereas only $51 \%$ (40\%) of domestic production is exported. On the other hand, $65 \%$ of domestic production of Meat and Meat Products is exported, whereas the import intensity with $29 \%$ is significantly lower. Thus, looking at both aspects of trade is important. Furthermore, comparing our two measures of export openness in the bottom part of the figure we note that, on average, industries with low values of $\operatorname{Exp}^{(1)}$ also have low values of $\operatorname{Exp}^{(2)}$ and vice versa. The two variables have a correlation coefficient of 0.7 . There are, however, some notable exceptions. For example, the export intensity in Mfr. of leather and footwear is very high, whereas the Danish market share in the EU 24 for this industry is low compared to other industries.

While the cross-sectional variation in trade openness is substantial, the variation across time

\footnotetext{
${ }^{11}$ We use the VAT statistics as a source of information on exports rather than Eurostat data, because in the latter we are confined to determine industry-wide exports based on the industry affiliation of the product code, rather than the industry affiliation of the firms.

${ }^{12}$ Exports to the EU 24 are constructed by multiplying aggregate exports to all markets with the share of exports to the EU 24 in overall exports.
} 
for a given industry is considerably lower. Nevertheless, some industries have undergone significant changes in trade openness on either the export and/or the import side. In contrast to e.g. tariffs, trade exposure reflects not only trade costs but more generally also the relative competitiveness of domestic firms on different markets. Figure 1 suggests that the international competitiveness of Danish firms has improved over the sample period in some industries, but deteriorated in others.

\subsubsection{Product differentiation}

Ideally, a verification of predictions 3 and $4 \mathrm{a} / 4 \mathrm{~b}$ would be based on estimates of $\sigma$ 's retrieved from industry-level demand equations. However, our data do not allow us to estimate such demand systems and we opt instead for measurable proxies for an industry's level of product differentiation.

Our preferred measure is based on the well-known classification of Rauch (1999), which distinguishes between three types of goods: goods "traded on organized exchange", "reference-priced" and "differentiated" goods. Evidence in Broda \& Weinstein (2006) supports the claim that products traded on organized exchange are more substitutable. Linking each product code to a specific industry, the share of differentiated goods in each industry constitutes our first measure of product differentiation.

Product differentiation is emphasized as one of the main factors giving rise to intra-industry trade; see e.g. Grubel \& Lloyd (1975), Krugman (1979). Our second measure of product differentiation is therefore based on the Grubel-Lloyd index of intra-industry trade. ${ }^{13}$ When constructed based on industry-level trade data, the index captures both product differentiation and foreign sourcing of intermediates (Colantone \& Sleuwaegen, 2010). To abstract from the latter, we compute the index for each product $n$. Subsequently, we obtain an industry-level measure as the weighted average of the indexes at the product level, ${ }^{14}$

$$
G L=\sum_{n=1}^{N} \omega^{n}\left(1-\frac{\left|\sum_{\ell \neq i} X_{i \ell}^{n}-\left(\sum_{\ell \neq i} X_{\ell i}^{n}\right)\right|}{\sum_{\ell \neq i} X_{i \ell}^{n}+\sum_{\ell \neq i} X_{\ell i}^{n}}\right) \quad \text { where } \quad \omega^{n} \equiv \frac{\sum_{\ell \neq i} X_{i \ell}^{n}+\sum_{\ell \neq i} X_{\ell i}^{n}}{\sum_{n}\left(\sum_{\ell \neq i} X_{i \ell}^{n}+\sum_{\ell \neq i} X_{\ell i}^{n}\right)},
$$

where $\omega^{n}$ is the within-industry trade share of product $n$ and the term in brackets in (8) is the product-specific Grubel-Lloyd. High values of $G L$ imply that two-way trade is important, which is in turn an indication of a high degree of product differentiation. $G L$ is time-variant and therefore takes into account changes in the product composition of trade. This is an advantage but also a drawback,

\footnotetext{
${ }^{13} \mathrm{~A}$ caveat to this approach is that with oligopolistic firms, two-way trade may occur even in homogeneous products (Brander \& Krugman, 1983). However, the Grubel-Lloyd index is highly negatively correlated with measures of industry concentration. It therefore seems implausible that intra-industry trade is driven by the oligopolistic behavior of firms.

${ }^{14}$ At this level of disaggregation, sourcing of intermediates and re-export of final goods are recorded in different product categories.
} 
since the product classification itself changes over time, causing artificial changes in the measured degree of product differentiation.

In our robustness analysis, we experiment with three additional proxies for the degree of product differentiation. In particular, due to the product-specific weights in (8), GL could be biased by the composition of trade towards certain products. We therefore also employ the unweighted average product-specific Grubel-Lloyd index, which does not suffer from such composition effects. Moreover, we follow Syverson (2004) and proxy product substitutability with a generalized Herfindahl-type product diversification index. This index takes into account both the number of industry products, as well the unequal shares of these different products in an industry's output. ${ }^{15}$ Finally, in a recent paper, Del Gatto et al. (2008) provide sector-specific estimates of the elasticity of substitution. Their industry classification is different from ours, but we can broadly link these estimates to our industries. ${ }^{16}$

The first four measures of differentiation can attain values in the closed unit interval, with a higher value signaling a higher degree of differentiation. The estimates of $\sigma$ from Del Gatto et al. (2008) are, to the contrary, negatively related to product differentiation.

\subsubsection{Further industry-level controls}

Empirical studies on firm exit highlight two sets of determinants of firm failure - barriers and (dis)incentives to exit; see Siegfried \& Evans (1994) for a review of this literature. In our empirical model, we include the share of fixed assets in turnover and employment growth as control variables. The former variable is a measure of industry sunk costs whereas the latter variable is an indicator of industry growth and therefore a disincentive to exit.

If the determinants of entry and exit processes are symmetric, controlling for entry in the exit equation may provoke misleading conclusions on the role of trade in shaping firm survival. ${ }^{17}$ On the other hand, barriers to entry are barriers to exit, and including entry in the exit equation eliminates or reduces the significance of all measures of exit barriers; see Shapiro \& Khemani (1987). Hence, controlling for entry can conveniently solve the omitted variable bias due to unobservable barriers to exit. ${ }^{18}$ Furthermore, displacement entry is an important empirical phenomenon. We therefore

\footnotetext{
${ }^{15}$ The index is given by $1-\sum_{n=1}^{N} s_{n}^{2}$, where $s_{n}$ is the share of product $n$ in overall industry imports and exports.

${ }^{16}$ While these estimates are the closest equivalents to $\sigma$ in our theoretical exposition, often several industries could only be assigned a common $\sigma$. The identifying variation on which cross-industry differences in the effect of trade exposure can be estimated is therefore limited and we only use these data in our robustness analysis.

${ }^{17}$ If entry depends on trade exposure, entry is a "bad control" variable because it was not fixed at the time trade exposure was determined; see Angrist \& Pischke (2009).

${ }^{18}$ Bernard \& Jensen (2007) employ the minimum of industry-level entry and exit rates as a measure of sunk costs. They note that, if all industries were in steady state, the industry entry rate would be a good proxy for sunk costs. In reality, some industries are expanding and others are contracting, which is captured by our measure of industry growth.
} 
estimate the empirical model both with and without entry as control.

\subsection{Econometric approach}

Our predictions relate industry-specific average probabilities of exit, $\widetilde{\delta}$, to the industry's trade exposure. In practice, however, we opt for a more flexible econometric specification and formulate a Poisson model for the count of exiting firms in industry $h$ in year $t .{ }^{19}$ That is, we take $\widetilde{\delta} M$ rather than $\widetilde{\delta}$ as dependent variable, but control for the number of firms $M$ in all specifications. ${ }^{20}$

Firms base their decision on staying in the market or exiting between $t$ and $t-1$ on information available at $t-1$. For a test of predictions $1,2 \mathrm{a}$ and $2 \mathrm{~b}$, the conditional mean is specified as

$$
E\left[\operatorname{exit}_{h t, t-1} \mid \cdot\right]=\exp \left(\beta_{0}+\beta_{1} \operatorname{Imp}_{h, t-1}+\beta_{2} \operatorname{Exp}_{h, t-1}+\gamma C_{h, t-1}+\delta_{t}+\delta_{H}\right)
$$

where $\operatorname{Exp}_{h, t-1}$ is one of our two alternative measures of export openness. Time fixed effects $\delta_{t}$ account for aggregate macroeconomic fluctuations and $C_{h, t-1}$ is a vector of industry-specific control variables, including the number of firms at time $t-1$.

The discussion in section 2 does not offer any insights on the time frame of adjustments needed for trade-related effects on firm exit to take effect. In particular, in the presence of sunk costs and due to hysteresis, short-run effects of trade on firm exit could well be negligible; see Roberts \& Tybout (1991) for a discussion. Pirotte (1999) shows that the within (fixed effects) estimator reflects short-run adjustments, whereas estimation of a static relation based on the between or pooled estimator reflects long-run effects. Our econometric specification follows this latter approach. To control for unobserved barriers to exit, our specification includes sector fixed effects $\delta_{H}$, corresponding to the 53-grouping of the Danish Industry Coding. At this level, the 31 manufacturing industries are aggregated into 12 sectors; see table A.1 in the appendix.

For an empirical test of predictions 3 and $4 \mathrm{a}$ versus $4 \mathrm{~b}$, the model is reformulated as

$$
\begin{aligned}
E\left[\operatorname{exit}_{h t, t-1} \mid \cdot\right]=\exp \left(\beta_{0}+\beta_{1} \operatorname{Imp}_{h, t-1}+\beta_{2} \operatorname{Exp}_{h, t-1}+\beta_{3} \sigma_{h}\right. \\
\left.+\beta_{13} I m p_{h, t-1} \times \sigma_{h}+\beta_{23} \operatorname{Exp}_{h, t-1} \times \sigma_{h}+\gamma C_{h, t-1}+\delta_{t}+\delta_{H}\right)
\end{aligned}
$$

where $\sigma_{h}$ is the elasticity of substitution in industry $h$, which is inversely related to product differ-

\footnotetext{
${ }^{19}$ The Poisson Pseudo Maximum Likelihood estimator is preferred to log-linearization of the model and estimation by Ordinary Least Squares because $(i)$ the dependent variable may take on the value zero and because (ii) in the presence of heteroskedasticity information on $E[\ln$ exit $\mid \cdot]$ does not allow to gather any information on E[exit|·] (Santos Silva \& Tenreyro, 2006). Robustness analysis employing the negative binomial model confirmed all of our results. With few clusters, the underlying asymptotic theory for obtaining cluster-robust standard errors does not apply. We therefore report the robust estimate of the standard error. Results are, however, robust to clustering at the industry level.

${ }^{20}$ Results show that the elasticity of the count of firm exits with respect to the number of firms is significantly different from one. Hence, taking the exit rate as dependent variable would be inappropriate for the data at hand.
} 
entiation. Due to the non-linearity of the Poisson model, $\beta_{13}$ is the interaction parameter, not to be confused with the interaction effect (Mullahy, 1999). Here, interest lies in how the effects of trade exposure vary with $\sigma_{h}$,

$$
\frac{\partial E[\text { exit } \mid \cdot]}{\partial \operatorname{Imp}} \frac{1}{E[\text { exit } \mid \cdot]}=\beta_{1}+\beta_{13} \times \sigma_{h} \quad \text { and } \quad \frac{\partial E[\text { exit } \mid \cdot]}{\partial E x p} \frac{1}{E[\text { exit } \mid \cdot]}=\beta_{2}+\beta_{23} \times \sigma_{h},
$$

which gives the percentage change in the number of firm exits due to a unit change in trade openness.

Import and export exposure include domestic sales in the denominator and/or exports in the numerator, which may lead to spurious correlation with firm failure. We therefore employ a set of three instruments to show that results can be interpreted as reflecting causal relations.

First, we instrument trade exposure by the average "bulkiness" of the goods traded in an industry, where bulkiness is given by the ratio of values to tonnage of shipments. Goods with a higher valueto-weight ratio are more economical to ship and exhibit lower barriers to trade. Since bulkiness is closely related to prices, it does not fulfill the exogeneity assumption when calculated based on the Danish trade data. Instead, we employ import data for Germany, available from the COMEXT database. Second, import exposure is higher and exporting opportunities are lower if competing firms are geographically closer to the Danish market. Hence, we construct a gravity-inspired instrument for trade exposure as the average output share of industry $h$ in other European economies, weighted by the inverse of the geographic distance from Denmark, Gravity ${ }_{h t}=\sum_{\ell}\left(\ln d i s t_{\ell}\right)^{-1} y_{h \ell t} / Y_{\ell t}$. These first two instruments build on Chen et al. (2009). Third, and inspired by Trefler (2004), we instrument trade exposure by the industry's skill intensity. ${ }^{21}$ Political economy models suggest that low-skill intensive industries exhibit higher degrees of import protection. When estimating (10), interaction terms between import penetration (export openness) and product differentiation are also potentially endogenous. In these specifications, interactions between our three instruments and the proxy for $\sigma_{h}$ serve as additional instruments.

In the instrumental variable approach, we consider two different estimators. The linear 2SLS estimator for the number of firm exits (in logs) allows for considerable testing on the relevance and validity of the instruments (Mullahy, 1997). The preferred estimator is then a structural Poisson-IV (Wooldridge, 2001), which controls for the possible endogeneity of the regressors by including the residuals from the first stage in the second stage regression.

\footnotetext{
${ }^{21}$ We use the average industry wage as a proxy for skill intensity. The export- "pull" works via wage increases and the instrument is therefore suspect at first sight. In a more realistic set-up with different types of labor inputs, we expect cross-industry differences in wages to be driven by differences in input intensities rather than by differences in the toughness of competition for labor inputs.
} 


\section{Empirical Results}

\subsection{Trade exposure and firm exit: benchmark results}

To assess our first three predictions on the role of import and export openness for aggregate firm failure, table 1 reports results from the benchmark specification in equation (9). Industries where import penetration is high are usually very open also regarding exports, which exacerbates parameter identification if both variables are included jointly. ${ }^{22}$ We therefore first include each of the trade exposure variables one at a time; see columns (1) to (3). In columns (4) to (7), the effect of Imp and $\operatorname{Exp}^{(1)}\left(\operatorname{Exp}^{(2)}\right)$ is then estimated jointly.

Across all specifications, we find strong support for prediction 1: Imp has a positive and statistically significant effect on the number of firms that exit an industry. Importantly, columns (4) to (7) show that this finding is robust to controlling for export openness. Our findings thereby lend credibility to previous studies that only consider an industry's import intensity, but neglect the role of the export market - and therefore might have suffered from an omitted variables bias.

We consequently go beyond import competition and investigate predictions $2 \mathrm{a}$ and $2 \mathrm{~b}$ on the role of export openness in shaping firms' survival prospects. Table 1 shows that both our measures of export openness are always estimated with positive coefficients, though statistical significance differs across specifications. When we only consider the exporting side in column (2), $\operatorname{Exp}^{(1)}$, has a positive and significant impact on firm exit. However, and in line with results in Colantone \& Sleuwaegen (2010), the coefficient on $\operatorname{Exp}^{(1)}$ turns insignificant once $\operatorname{Imp}$ is controlled for in column (4). This loss in both statistical significance and magnitude may however simply be due to multicollinearity. Accordingly, we next turn to our novel measure of export openness, which sidesteps the multicollinearity issue and thereby helps to disentangle the effects of import and export openness. Domestic penetration of the European market, $\operatorname{Exp}^{(2)}$, has a positive and significant impact on aggregate firm failure once we control for the industry's import intensity in column (5) and (7).

The export market therefore further contributes to the selection effect of trade, in line with the export-"pull", which seems to outweigh the beneficial effect (if any) of exporting opportunities. While we are not in a position to directly test for the assumed underlying positive link between exports and industry-wide wages, our findings accord well with the evidence: empirically, exporters pay higher wages and have higher employment growth; see Bernard et al. (2007). Furthermore, exporters increase their wages in response to a decline in trade barriers (Amiti \& Davis, 2011; Krishna et al., 2011).

\footnotetext{
${ }^{22}$ The correlation coefficient between $\operatorname{Imp}$ and $\operatorname{Exp}^{(1)}\left(\operatorname{Exp}^{(2)}\right)$ is $0.75(0.13)$.
} 
Table 1: Trade exposure and firm exit: Benchmark results ${ }^{\mathrm{a}}$

\begin{tabular}{|c|c|c|c|c|c|c|c|}
\hline & \multicolumn{7}{|c|}{ Poisson model with sector fixed effects } \\
\hline & $(1)$ & $(2)$ & $(3)$ & $(4)$ & $(5)$ & $(6)$ & $(7)$ \\
\hline$I m p_{t-1}$ & $\begin{array}{l}0.584^{* * *} \\
(0.149)\end{array}$ & & & $\begin{array}{l}0.488^{* * *} \\
(0.179)\end{array}$ & $\begin{array}{l}0.653^{* * *} \\
(0.153)\end{array}$ & $\begin{array}{l}0.350^{* *} \\
(0.160)\end{array}$ & $\begin{array}{l}0.522^{* * *} \\
(0.129)\end{array}$ \\
\hline $\operatorname{Exp}_{t-1}^{(1)}$ & & $\begin{array}{l}0.654^{* * *} \\
(0.221)\end{array}$ & & $\begin{array}{l}0.286 \\
(0.264)\end{array}$ & & $\begin{array}{l}0.355 \\
(0.229)\end{array}$ & \\
\hline $\operatorname{Exp}_{t-1}^{(2)}$ & & & $\begin{array}{l}9.362 \\
(6.248)\end{array}$ & & $\begin{array}{l}15.91^{* * *} \\
(6.131)\end{array}$ & & $\begin{array}{l}11.86^{* *} \\
(5.609)\end{array}$ \\
\hline $\log$ Firms $_{t-1}$ & $\begin{array}{l}1.158^{* * *} \\
(0.0348)\end{array}$ & $\begin{array}{l}1.122^{* * *} \\
(0.0339)\end{array}$ & $\begin{array}{l}1.073^{* * *} \\
(0.0308)\end{array}$ & $\begin{array}{l}1.169^{* * *} \\
(0.0362)\end{array}$ & $\begin{array}{l}1.188^{* * *} * \\
(0.0393)\end{array}$ & $\begin{array}{l}0.812^{* * *} \\
(0.0433)\end{array}$ & $\begin{array}{l}0.827 * * * \\
(0.0449)\end{array}$ \\
\hline Fixed Assets $t-1$ & $\begin{array}{l}-0.455^{* * * *} \\
(0.142)\end{array}$ & $\begin{array}{l}-0.551^{* * *} \\
(0.149)\end{array}$ & $\begin{array}{l}-0.479^{* * *} \\
(0.149)\end{array}$ & $\begin{array}{l}-0.500^{* * *} \\
(0.150)\end{array}$ & $\begin{array}{l}-0.518^{* * *} \\
(0.146)\end{array}$ & $\begin{array}{c}-0.213^{*} \\
(0.121)\end{array}$ & $\begin{array}{c}-0.209^{*} \\
(0.117)\end{array}$ \\
\hline Employment Growth $_{t-1, t-2}$ & $\begin{array}{l}-0.250 \\
(0.223)\end{array}$ & $\begin{array}{l}-0.309 \\
(0.239)\end{array}$ & $\begin{array}{l}-0.369 \\
(0.242)\end{array}$ & $\begin{array}{l}-0.244 \\
(0.227)\end{array}$ & $\begin{array}{l}-0.248 \\
(0.228)\end{array}$ & $\begin{array}{c}-0.359^{*} \\
(0.200)\end{array}$ & $\begin{array}{c}-0.362^{*} \\
(0.199)\end{array}$ \\
\hline Product Differentiation (Rauch) & $\begin{array}{l}0.176 \\
(0.116)\end{array}$ & $\begin{array}{l}0.278^{* *} \\
(0.113)\end{array}$ & $\begin{array}{l}0.207^{*} \\
(0.107)\end{array}$ & $\begin{array}{l}0.207^{*} \\
(0.122)\end{array}$ & $\begin{array}{l}0.139 \\
(0.118)\end{array}$ & $\begin{array}{l}0.328^{* * *} \\
(0.0872)\end{array}$ & $\begin{array}{l}0.258^{* * *} \\
(0.0875)\end{array}$ \\
\hline $\log _{\text {Entry }}, t-1$ & & & & & & $\begin{array}{l}0.323^{* * *} \\
(0.0327) \\
\end{array}$ & $\begin{array}{l}0.317^{* * *} \\
(0.0333)\end{array}$ \\
\hline $\begin{array}{l}\text { Percentage change in exit due to } \\
\text { - one std. dev. increase in } \operatorname{Imp} \\
\text { - one std. dev. increase in } \operatorname{Exp}^{(1)} \\
\text { - one std. dev. increase in } \operatorname{Exp}^{(2)}\end{array}$ & 15.68 & 15.94 & 4.33 & $\begin{array}{l}12.94 \\
6.68\end{array}$ & $\begin{array}{l}17.70 \\
7.48\end{array}$ & $\begin{array}{l}9.13 \\
8.37\end{array}$ & $\begin{array}{l}13.90 \\
5.52 \\
\end{array}$ \\
\hline $\begin{array}{l}\text { Observations } \\
\text { Pseudo- } R^{2}\end{array}$ & $\begin{array}{l}207 \\
0.864\end{array}$ & $\begin{array}{l}207 \\
0.863\end{array}$ & $\begin{array}{l}207 \\
0.861\end{array}$ & $\begin{array}{l}207 \\
0.864\end{array}$ & $\begin{array}{l}207 \\
0.865\end{array}$ & $\begin{array}{l}207 \\
0.875\end{array}$ & $\begin{array}{l}207 \\
0.875\end{array}$ \\
\hline
\end{tabular}

Regressions based on $\operatorname{Exp}^{(2)}$ suggest that import penetration is quantitatively more important in explaining trade-induced firm failure: increasing $\operatorname{Imp}$ by one standard deviation leads to an increase in firm exit of 16 to 20 percent, whereas a comparable increase in $\operatorname{Exp}^{(2)}$ implies a 4 to 8 percent increase in firm exit. Notably, however, quantitative implications drawn from parameter estimates of $\operatorname{Exp}^{(1)}$ - though often not significant - are suggestive of almost symmetric effects of export and import openness; see columns (1) vs. (2) and (6).

In the last two columns of table 1, we include firm entry in order to control for displacement entry as well as unobserved barriers to exit. Magnitudes are slightly reduced compared to previous estimates, but qualitative predictions persist. Log entry has a positive effect on firm failure, in line with the displacement entry interpretation. The estimated elasticity of exit with respect to industry size is close to one and all other control variables enter with the expected signs, though their effect is often estimated imprecisely. Finally, firm exit is significantly higher in differentiated industries.

We also address the issue of potential endogeneity of the trade exposure variables using our set of three instruments; see table 2. Instrument relevance can be judged by looking at the $F$ test for joint significance of the three instruments in the first stage regressions. The $F$ test is, with one exception, always above the critical value of 10 . The Hansen $J$ test from the 2SLS regressions furthermore supports the validity of the instruments; see columns (1) to (4). Exogeneity of import and export exposures is rejected in the 2SLS estimations, but cannot be rejected in some of the structural PoissonIV specifications. Importantly, all qualitative results from our benchmark model are confirmed in the 
Table 2: Trade exposure and firm exit: IV results ${ }^{\mathrm{a}}$

\begin{tabular}{|c|c|c|c|c|c|c|c|c|}
\hline & \multicolumn{4}{|c|}{ 2SLS linear } & \multicolumn{4}{|c|}{ IV Poisson model } \\
\hline & $(1)$ & $(2)$ & $(3)$ & $(4)$ & $(5)$ & $(6)$ & $(7)$ & $(8)$ \\
\hline$I m p_{t-1}$ & $\begin{array}{l}1.230^{* *} \\
(0.548)\end{array}$ & $\begin{array}{l}1.539^{* * *} \\
(0.535)\end{array}$ & $\begin{array}{l}1.382^{* * *} \\
(0.526)\end{array}$ & $\begin{array}{l}1.642^{* * *} \\
(0.545)\end{array}$ & $\begin{array}{l}0.923^{* *} \\
(0.377)\end{array}$ & $\begin{array}{l}1.316^{* * *} \\
(0.446)\end{array}$ & $\begin{array}{l}0.782^{* *} \\
(0.359)\end{array}$ & $\begin{array}{l}1.063^{* * *} \\
(0.393)\end{array}$ \\
\hline $\operatorname{Exp}_{t-1}^{(1)}$ & $\begin{array}{l}2.632^{* * *} \\
(0.701)\end{array}$ & & $\begin{array}{l}1.965^{* * *} \\
(0.600)\end{array}$ & & $\begin{array}{l}2.693^{* * *} \\
(0.516)\end{array}$ & & $\begin{array}{l}1.407^{* * *} \\
(0.450)\end{array}$ & \\
\hline $\operatorname{Exp}_{t-1}^{(2)}$ & & $\begin{array}{l}66.05^{* * *} \\
(16.79)\end{array}$ & & $\begin{array}{l}53.01^{* * *} \\
(15.83)\end{array}$ & & $\begin{array}{l}73.78^{* * *} \\
(13.49)\end{array}$ & & $\begin{array}{l}42.43^{* * *} \\
(12.21)\end{array}$ \\
\hline $\log$ Firms $_{t-1}$ & $\begin{array}{l}1.200 * * * \\
(0.0585)\end{array}$ & $\begin{array}{l}1.154^{* * *} \\
(0.0466)\end{array}$ & $\begin{array}{l}0.883^{* * *} \\
(0.0967)\end{array}$ & $\begin{array}{l}0.879 * * * \\
(0.0920)\end{array}$ & $\begin{array}{l}1.219 * * * \\
(0.0416)\end{array}$ & $\begin{array}{l}1.203^{* * *} \\
(0.0418)\end{array}$ & $\begin{array}{l}0.850^{* * *} \\
(0.0519)\end{array}$ & $\begin{array}{l}0.854^{* * * *} \\
(0.0520)\end{array}$ \\
\hline Fixed Assets A $_{t-1}$ & $\begin{array}{l}-0.526^{* *} \\
(0.228)\end{array}$ & $\begin{array}{l}-0.402^{* *} \\
(0.190)\end{array}$ & $\begin{array}{l}-0.419^{* *} \\
(0.203)\end{array}$ & $\begin{array}{c}-0.345^{*} \\
(0.179)\end{array}$ & $\begin{array}{l}-0.618^{* * *} \\
(0.157)\end{array}$ & $\begin{array}{l}-0.677^{* * *} \\
(0.160)\end{array}$ & $\begin{array}{l}-0.357^{* *} \\
(0.157)\end{array}$ & $\begin{array}{l}-0.361^{* *} \\
(0.156)\end{array}$ \\
\hline $\begin{array}{l}\text { Employment }^{\text {Growth }}+1 \\
\text { Grow }_{t-1}\end{array}$ & $\begin{array}{l}0.125 \\
(0.376)\end{array}$ & $\begin{array}{l}-0.202 \\
(0.347)\end{array}$ & $\begin{array}{l}0.170 \\
(0.363)\end{array}$ & $\begin{array}{l}-0.0780 \\
(0.340)\end{array}$ & $\begin{array}{l}0.106 \\
(0.254)\end{array}$ & $\begin{array}{l}-0.174 \\
(0.254)\end{array}$ & $\begin{array}{l}-0.0853 \\
(0.269)\end{array}$ & $\begin{array}{l}-0.234 \\
(0.248)\end{array}$ \\
\hline $\begin{array}{l}\text { Product Diff. } \\
\text { (Rauch) }\end{array}$ & $\begin{array}{l}1.356^{* * *} \\
(0.393)\end{array}$ & $\begin{array}{l}0.762 * * * \\
(0.291)\end{array}$ & $\begin{array}{l}1.269 * * * \\
(0.347)\end{array}$ & $\begin{array}{l}0.834^{* * *} \\
(0.261)\end{array}$ & $\begin{array}{l}1.014^{* * *} \\
(0.269)\end{array}$ & $\begin{array}{l}0.423^{* *} \\
(0.208)\end{array}$ & $\begin{array}{l}0.744^{* * *} \\
(0.238)\end{array}$ & $\begin{array}{l}0.456^{* *} \\
(0.180)\end{array}$ \\
\hline $\log _{\text {Entry }} t, t-1$ & & & $\begin{array}{l}0.316^{* * *} \\
(0.0818)\end{array}$ & $\begin{array}{l}0.286^{* * *} \\
(0.0770)\end{array}$ & & & $\begin{array}{l}0.328^{* * *} \\
(0.0378)\end{array}$ & $\begin{array}{l}0.315^{* * *} * \\
(0.0385)\end{array}$ \\
\hline \multicolumn{9}{|c|}{ Percentage change in exit due to } \\
\hline $\begin{array}{l}\text { - std. dev. increase in } \operatorname{Imp} \\
\text { - std. dev. increase in Exp }\end{array}$ & & & & & $\begin{array}{l}27.17 \\
90.11 \\
\end{array}$ & $\begin{array}{l}40.86 \\
39.74 \\
\end{array}$ & $\begin{array}{l}22.58 \\
39.88 \\
\end{array}$ & $\begin{array}{l}31.89 \\
21.22 \\
\end{array}$ \\
\hline Observations & 206 & 206 & 205 & 205 & 208 & 208 & 207 & 207 \\
\hline$R^{2} /$ Pseudo- $R^{2}$ & 0.87 & 0.90 & 0.90 & 0.92 & 0.87 & 0.87 & 0.88 & 0.88 \\
\hline Hansen $J$-test $(p)^{\mathrm{b}}$ & 0.81 & 0.19 & 0.88 & 0.45 & - & - & - & - \\
\hline Endogeneity $I m p^{\mathrm{c}}$ & 0.00 & 0.02 & 0.00 & 0.00 & -0.0952 & -0.708 & -0.281 & -0.569 \\
\hline Endogeneity $E x p^{\mathrm{c}}$ & 0.00 & 0.00 & 0.00 & 0.00 & $-3.452^{* * *}$ & $-78.83^{* * *}$ & $-1.525^{* * *}$ & $-40.16^{* * *}$ \\
\hline
\end{tabular}

IV framework. However, quantitative predictions - in particular for the export market - increase subtantially. ${ }^{23}$

\subsection{The role of product differentiation}

Traditionally, it has been argued that product differentiation shields firms from international competition, by making consumers less price responsive; see e.g. Greenaway et al. (2008). However, our analysis preceding prediction 3 suggests at least two countervailing forces: only with low-elasticities of substitution do imported varieties have a substantial impact on the domestic price index. Moreover, product differentiation may also influence the market structure of an industry.

In support of this last consideration, figure 2 provides evidence on the link between product differentiation and market structure. The first two graphs highlight a significant negative relationship between product differentiation and industry concentration, as measured either by the 4-firm concentration ratio or the Herfindahl-Hirschmann index. ${ }^{24}$ Furthermore, figure 2(c) shows that highly

\footnotetext{
${ }^{23}$ Bernard et al. (2006) argue that the substantial increase in the IV coefficients may be due to non-classical measurement error in import penetration.

${ }^{24}$ Data on 4-Firm Concentration Ratios and the Herfindahl-Hirschmann Index is retrieved from Denmark statistics. Measures of industry concentration are only meaningful at higher levels of disaggregation, and therefore not available at the level of aggregation of the business demography data. We therefore take the unweighted average of the CR4 ratio (the Herfindahl-Hirschmann index) in the sub-industries that are matched to each of our 31 manufacturing industries.
} 
Figure 2: Product differentiation and industry structure ${ }^{\mathrm{a}}$

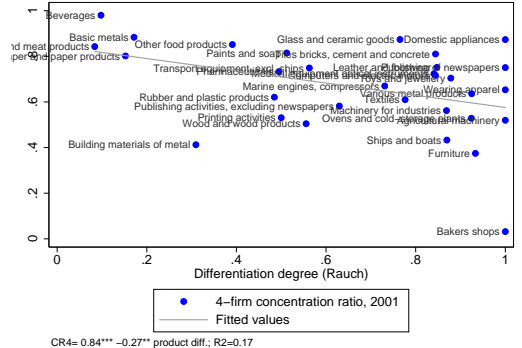

(a) 4-Firm Concentration Ratio

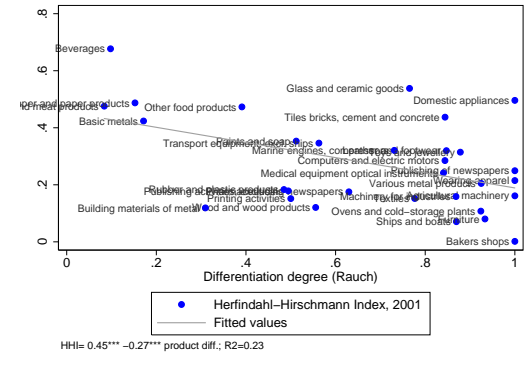

(b) Herfindahl-Hirschmann Index

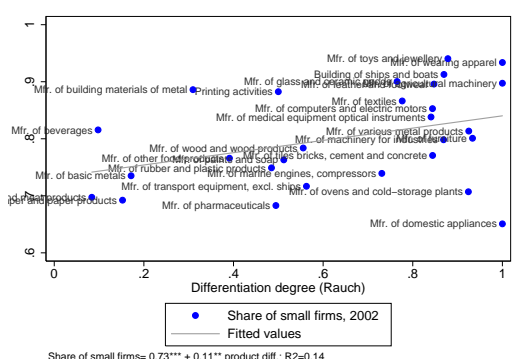

(c) Share of small firms

differentiated industries are on average characterized by a significantly higher share of small firms. While the relationship between product differentiation and market structure is only loose, differences in product differentiation can explain between 14 and $23 \%$ of inter-industry differences in market structure.

Given these observations, table 3 reports results from the empirical specification in equation (10) for our two baseline proxies of product differentiation based on Rauch (1999) and the Grubel-Lloyd index; see columns (1) to (4) and columns (5) to (8), respectively. As before, we report parameter estimates from specifications $(i)$ for either $\operatorname{Exp}^{(1)}$ or $\operatorname{Exp}^{(2)}$, and $(i i)$ with and without firm entry as additional control variable.

Import openness has a positive impact on firm failure, which is increasing in the degree of product differentiation. This finding is also by large robust across specifications, though cross-industry differences in the impact of imports turn insignificant in columns (6) and (8). To get some sense of the quantitative implications, figures 3(a) and 4(a) visualize how the impact of Imp varies with our proxies for $\sigma_{h}$; see equation (11). ${ }^{25}$ From the confidence intervals, the effect of import competition is insignificant if product differentiation is low, but becomes positive and statistically significant at higher levels. These results are strikingly at odds with the traditional view that differentiation shields firms from international competition. However, the higher impact of import openness in differentiated industries can plausibly be related to cross-sectional differences in industry structure, as revealed in figure 2. If an industry is dominated by a few large firms, import competition may induce losses of market shares without causing any firm failure. To the contrary, small firms - which are predominant particularly in highly differentiated industries - may be more vulnerable to import competition.

This aggregation problem needs to be borne in mind when interpreting the figures. Data on the share of small firms is from Eurostat's Structural Business Statistics for the industries as listed in table A.1, except for Publishing of newspapers and Publishing activities, excluding newspapers. Firms are classified as small if they have less than 20 employees.

${ }^{25}$ Figures 3(a) and 3(b) are based on column (3) of table 3. Figure 3(c) is based on column (4) of table 3. Figures $4(\mathrm{a})$ and 4(b) are based on column (7) of table 3. Figure 4(c) is based on column (8) of table 3. 
Table 3: The role of product differentiation ${ }^{\mathrm{a}}$

\begin{tabular}{|c|c|c|c|c|c|c|c|c|}
\hline & \multicolumn{4}{|c|}{ Differentiation degree (Rauch) } & \multicolumn{4}{|c|}{ Differentiation degree (GL) } \\
\hline & (1) & $(2)$ & $(3)$ & (4) & (5) & (6) & (7) & (8) \\
\hline$I m p_{t-1}$ & $\begin{array}{l}-0.866^{* * *} \\
(0.323)\end{array}$ & $\begin{array}{l}-0.723^{* *} \\
(0.339)\end{array}$ & $\begin{array}{l}-0.529^{*} \\
(0.280)\end{array}$ & $\begin{array}{l}-0.333 \\
(0.289)\end{array}$ & $\begin{array}{l}-0.494 \\
(0.403)\end{array}$ & $\begin{array}{l}0.771^{* *} \\
(0.336)\end{array}$ & $\begin{array}{l}-0.324 \\
(0.394)\end{array}$ & $\begin{array}{l}0.463 \\
(0.347)\end{array}$ \\
\hline $\begin{array}{l}\operatorname{Imp}_{t-1} \times \\
\quad \text { Product Diff. } t-1\end{array}$ & $\begin{array}{l}2.114^{* * * *} \\
(0.441)\end{array}$ & $\begin{array}{l}1.964 * * * \\
(0.432)\end{array}$ & $\begin{array}{l}1.416^{* * *} \\
(0.408)\end{array}$ & $\begin{array}{l}1.248^{* * *} \\
(0.384)\end{array}$ & $\begin{array}{l}1.529 * * \\
(0.723)\end{array}$ & $\begin{array}{l}-0.114 \\
(0.577)\end{array}$ & $\begin{array}{l}1.294^{*} \\
(0.713)\end{array}$ & $\begin{array}{l}0.378 \\
(0.608)\end{array}$ \\
\hline $\operatorname{Exp}_{t-1}^{(1)}$ & $\begin{array}{l}0.878^{* *} \\
(0.446)\end{array}$ & & $\begin{array}{l}0.941^{* * *} \\
(0.365)\end{array}$ & & $\begin{array}{l}2.213^{* * *} \\
(0.410)\end{array}$ & & $\begin{array}{l}1.561^{* * *} \\
(0.417)\end{array}$ & \\
\hline $\begin{array}{l}\operatorname{Exp}_{t-1}^{(1)} \times \\
\quad \text { Product Diff. } t-1\end{array}$ & $\begin{array}{l}-1.308^{* *} \\
(0.659)\end{array}$ & & $\begin{array}{l}-1.249^{* *} \\
(0.568)\end{array}$ & & $\begin{array}{l}-2.891^{* * *} \\
(0.801)\end{array}$ & & $\begin{array}{l}-2.222^{* * *} \\
(0.787)\end{array}$ & \\
\hline $\operatorname{Exp}_{t-1}^{(2)}$ & & $\begin{array}{l}20.93 \\
(13.97)\end{array}$ & & $\begin{array}{l}28.74^{* *} \\
(11.91)\end{array}$ & & $\begin{array}{l}99.14^{* * *} \\
(16.57)\end{array}$ & & $\begin{array}{l}78.65^{* * * *} \\
(16.11)\end{array}$ \\
\hline $\begin{array}{l}\operatorname{Exp}_{t-1}^{(2)} \times \\
\quad \text { Product Diff. } t-1\end{array}$ & & $\begin{array}{l}-20.64 \\
(18.90)\end{array}$ & & $\begin{array}{l}-32.10^{* *} \\
(16.19)\end{array}$ & & $\begin{array}{l}-175.0 * * * \\
(33.05)\end{array}$ & & $\begin{array}{l}-134.3^{* * *} \\
(32.36)\end{array}$ \\
\hline Product Diff. $t-1$ & $\begin{array}{l}-0.150 \\
(0.201)\end{array}$ & $\begin{array}{l}-0.559^{* * *} \\
(0.215)\end{array}$ & $\begin{array}{l}0.233 \\
(0.168)\end{array}$ & $\begin{array}{l}-0.129 \\
(0.174)\end{array}$ & $\begin{array}{l}1.671^{* * *} \\
(0.236)\end{array}$ & $\begin{array}{l}2.086^{* * *} \\
(0.265)\end{array}$ & $\begin{array}{l}1.238^{* * *} \\
(0.237)\end{array}$ & $\begin{array}{l}1.303^{* * *} \\
(0.334)\end{array}$ \\
\hline $\log$ Firms $_{t-1}$ & $\begin{array}{l}1.103^{* * *} \\
(0.0330)\end{array}$ & $\begin{array}{l}1.069^{* * *} \\
(0.0340)\end{array}$ & $\begin{array}{l}0.833^{* * *} \\
(0.0435)\end{array}$ & $\begin{array}{l}0.790^{* * *} \\
(0.0446)\end{array}$ & $\begin{array}{l}1.098 * * * \\
(0.0378)\end{array}$ & $\begin{array}{l}1.102^{* * *} \\
(0.0413)\end{array}$ & $\begin{array}{l}0.921^{* * *} \\
(0.0487)\end{array}$ & $\begin{array}{l}0.932^{* * *} \\
(0.0545)\end{array}$ \\
\hline Fixed Assets $t-1$ & $\begin{array}{l}-0.405^{* * *} \\
(0.153)\end{array}$ & $\begin{array}{l}-0.429 * * * \\
(0.148)\end{array}$ & $\begin{array}{l}-0.187 \\
(0.126)\end{array}$ & $\begin{array}{l}-0.158 \\
(0.116)\end{array}$ & $\begin{array}{l}-0.330^{* * *} \\
(0.119)\end{array}$ & $\begin{array}{c}-0.226^{*} \\
(0.117)\end{array}$ & $\begin{array}{c}-0.207^{*} \\
(0.111)\end{array}$ & $\begin{array}{l}-0.122 \\
(0.111)\end{array}$ \\
\hline $\begin{array}{l}\text { Employment } \\
\text { Growth }_{t-1, t-2}\end{array}$ & $\begin{array}{l}-0.172 \\
(0.202)\end{array}$ & $\begin{array}{l}-0.133 \\
(0.213)\end{array}$ & $\begin{array}{c}-0.324^{*} \\
(0.181)\end{array}$ & $\begin{array}{l}-0.286 \\
(0.188)\end{array}$ & $\begin{array}{l}-0.264 \\
(0.184)\end{array}$ & $\begin{array}{c}-0.313^{*} \\
(0.178)\end{array}$ & $\begin{array}{c}-0.343^{*} \\
(0.182)\end{array}$ & $\begin{array}{c}-0.345^{*} \\
(0.182)\end{array}$ \\
\hline $\log _{\text {Entry }}, t-1$ & & & $\begin{array}{l}0.277^{* * *} \\
(0.0336)\end{array}$ & $\begin{array}{l}0.287^{* * *} \\
(0.0350)\end{array}$ & & & $\begin{array}{l}0.170^{* * *} \\
(0.0352)\end{array}$ & $\begin{array}{l}0.179 * * * \\
(0.0432)\end{array}$ \\
\hline Observations & 215 & 208 & 214 & 207 & 208 & 201 & 208 & 201 \\
\hline Pseudo- $R^{2}$ & 0.867 & 0.870 & 0.874 & 0.877 & 0.869 & 0.872 & 0.872 & 0.875 \\
\hline
\end{tabular}

Figure 3: The conditional effect of trade exposure: Rauch

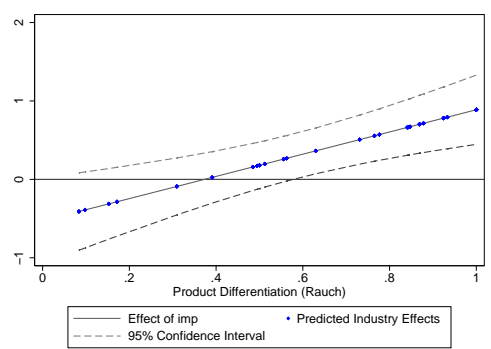

(a) Imp

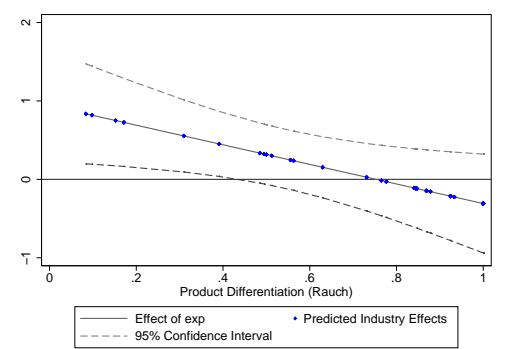

(b) $\operatorname{Exp}(1)$

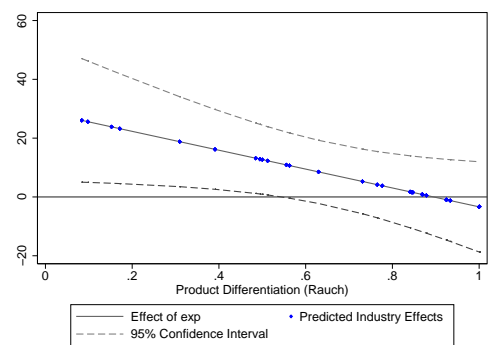

(c) $\operatorname{Exp}(2)$

Figure 4: The conditional effect of trade exposure: GL

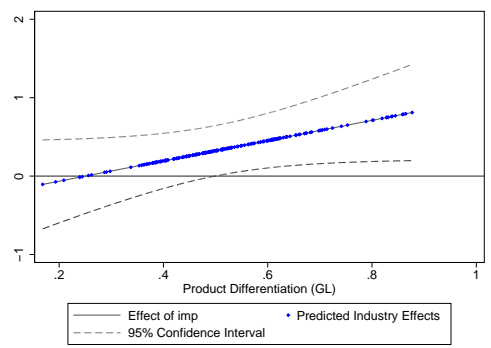

(a) Imp

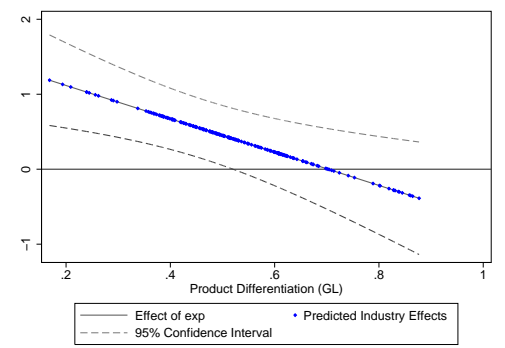

(b) $\operatorname{Exp}(1)$

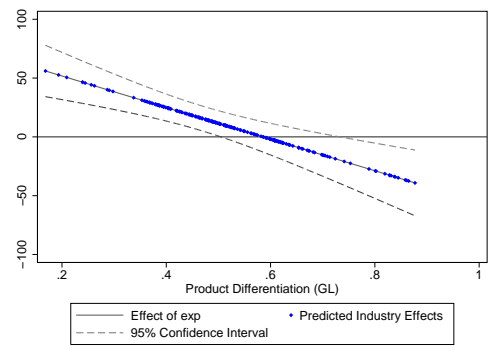

(c) $\operatorname{Exp}(2)$

Interestingly, product differentiation reduces the pro-competitive effects of trade when we consider the export market: the interaction between both of our export openness measures and the degree of product differentiation enters negatively in all specifications. Figures 3(b), 3(c), 4(b) and 4(c) plot 
Table 4: The role of product differentiation: IV results ${ }^{\mathrm{a}}$

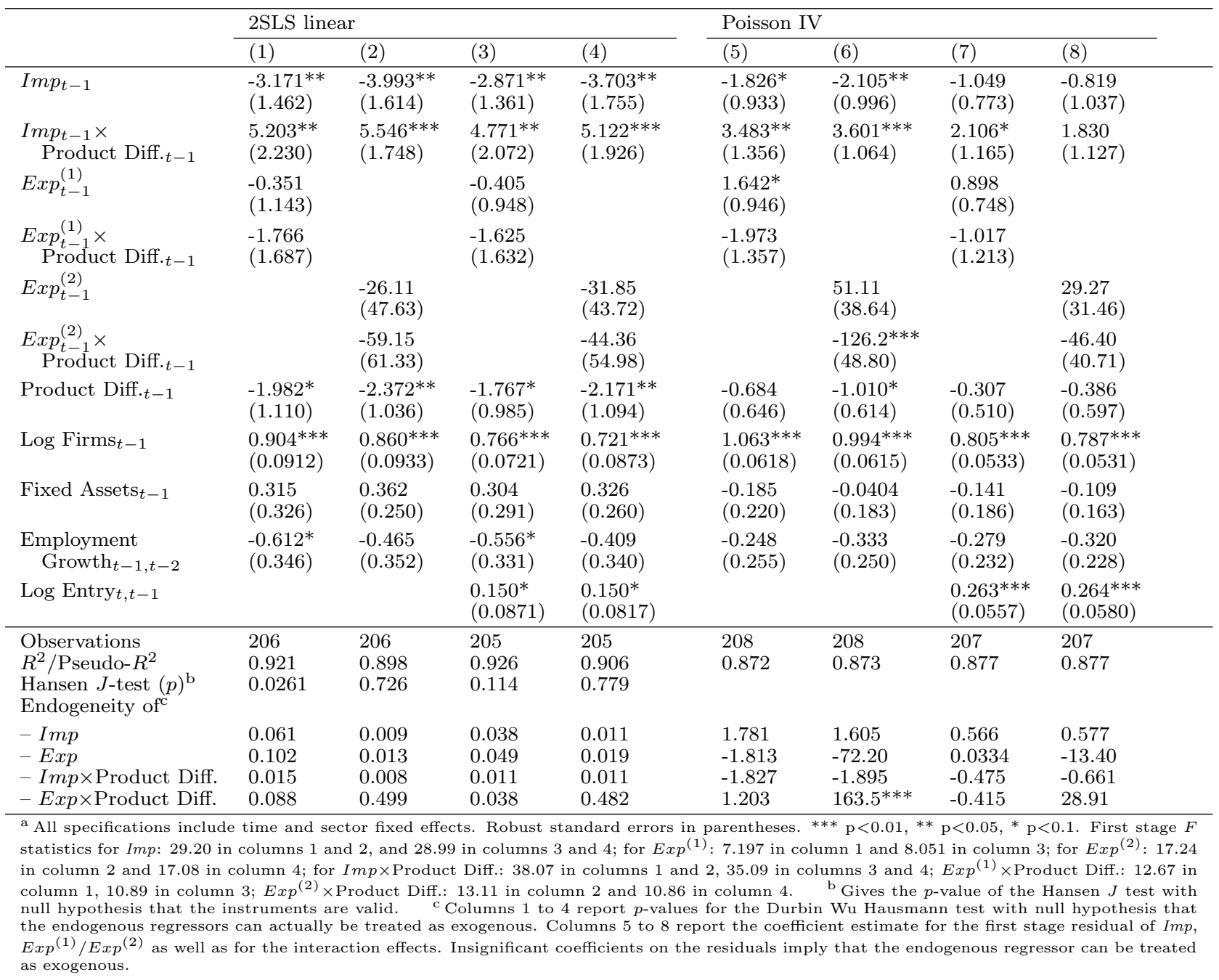

the impact of export openness as a function of product differentiation. Export exposure increases exit in industries where products are highly substitutable, whereas it (weakly) decreases firm failure if the degree of product differentiation is sufficiently high. This negative effect at the right-hand side of the graphs is, however, only significantly different from zero in figure 4(c). The "pull" of the export market is substantial in industries characterized by a low degree of product differentiation, where an increased demand for factor inputs at exporting firms crowds out purely domestic firms (and potentially also small exporters). This effect is considerably reduced in industries where products are highly differentiated. In these industries, increases in export exposure are mainly driven by the extensive margin, i.e. firms starting to export. Because these new exporters are relatively small, increased profit opportunities from exporting have a high impact on their individual probability of exit, and therefore also decrease aggregate firm failure.

In table 4, we report results from our instrumental variable approach for both 2SLS as well as 
Poisson-IV regressions. ${ }^{26}$ IV results again confirm previous estimates in qualitative terms: competition from imports has a higher impact in differentiated industries, whereas the opposite holds for export openness. This latter effect is very imprecisely estimated, but the Poisson-IV indeed largely rejects endogeneity of the potentially endogenous regressors.

Taken together, results confirm that trade exposure always increases firm failure, but the channel through which this increase is manifested differs across industries: it is mainly driven by the import"push" if products are differentiated, whereas it is driven by the export- "pull" if product differentiation is low.

\subsection{Robustness analysis}

The empirical analysis is motivated by the monopolistic competition framework. However, the high concentration ratios for some industries seen in figure 2 suggest that a model with a large number of monopolistically competitive firms that take market aggregates as given may not be suitable for all industries. In order to confront this caveat, we run two sets of robustness checks that aim to restrict the sample to industries that are more likely to accord well with the theoretical framework: first, we restrict the sample to those 26 industries with on average more than 100 firms in a given year. Second, we drop all highly concentrated industries with a Herfindahl-Hirschmann Index above 0.4. ${ }^{27}$ These regressions substantiate all of our conclusions from the benchmark model in table 1. Moreover, predictions regarding the variation in the impact of trade across industries are even amplified.

We also acknowledge the fact that our measures of product differentiation are only proxies for cross-industries differences in the elasticity of substitution. We therefore re-estimate the empirical model using the three alternative indicators of product substitutability described above. The results are summarized in figures 5 to 7 , which are based on specifications mirroring those in columns (7) and (8) of table 3. For both the unweighted Grubel-Lloyd index as well as for our product diversification index, the pattern of trade-induced effects on firm failure across industries is confirmed. And despite limited cross-industry variation in the $\sigma$ 's retrieved from Del Gatto et al. (2008), even these last estimates corroborate the conclusion that import competition is more detrimental in highly differentiated industries (i.e. low $\sigma$ industries); see figure $7(\mathrm{a})$. In fact, the only inconsistency with previous results is found in figure 7(c), which may simply reflect the circumstance that sample variation in $\sigma$ is low and effects are therefore very imprecisely estimated.

\footnotetext{
${ }^{26}$ First stage $F$ statistics are low in specifications with the Grubel Lloyd index, and we therefore do not present these results. Potentially, interactions between the three instruments and the proxy for $\sigma_{h}$ offer three additional instruments. However, we excluded the interaction with "bulkiness", since this resulted in a better fit in the first stage regressions.

${ }^{27}$ Results are also robust to directly controlling for industry concentration.
} 
Figure 5: The conditional effect of trade exposure: unweighted GL

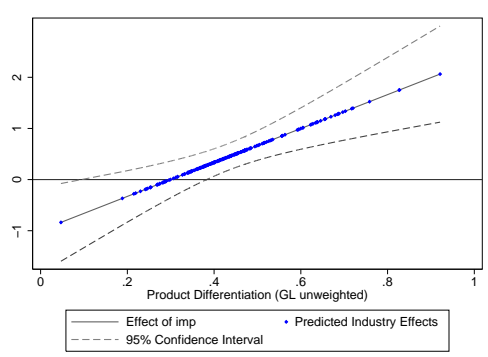

(a) Imp

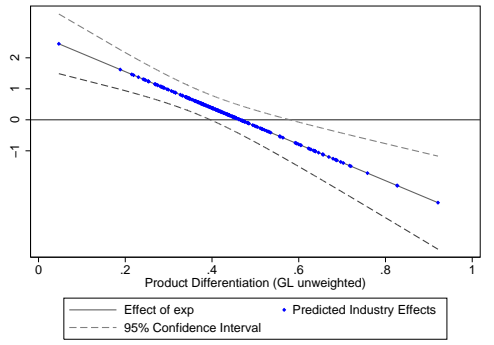

(b) $\operatorname{Exp}(1)$

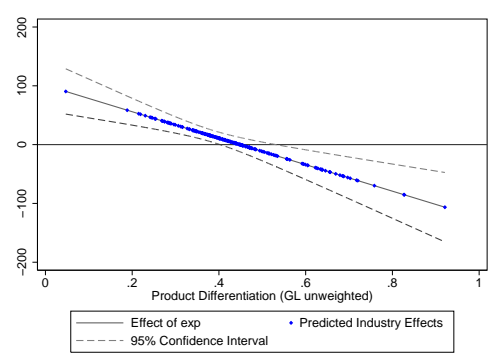

(c) $\operatorname{Exp}(2)$

Figure 6: The conditional effect of trade exposure: Product diversification index

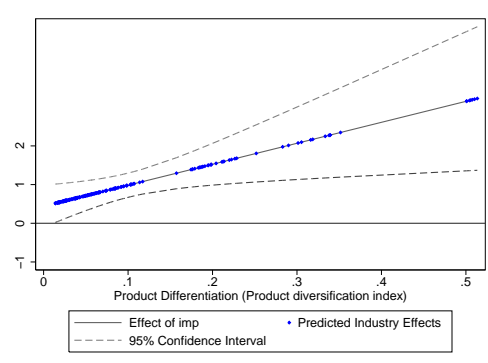

(a) Imp

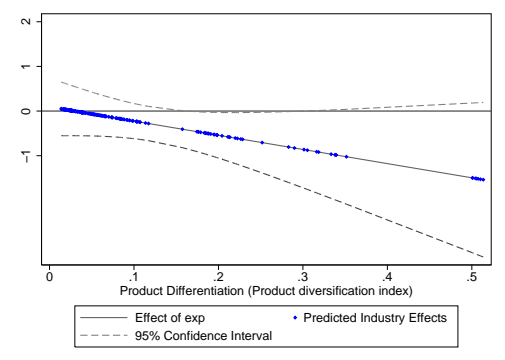

(b) $\operatorname{Exp}(1)$

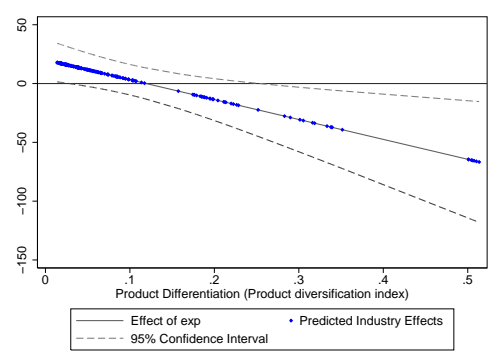

(c) $\operatorname{Exp}(2)$

Figure 7: The conditional effect of trade exposure: Sigma

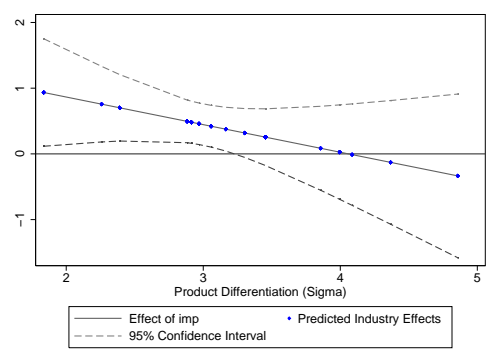

(a) Imp

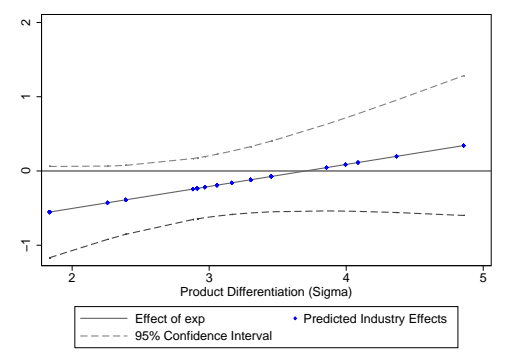

(b) $\operatorname{Exp}(1)$

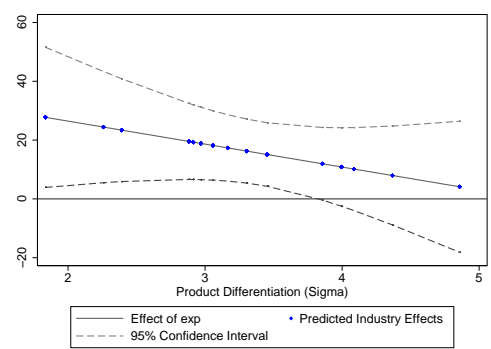

(c) $\operatorname{Exp}(2)$

\section{Conclusion}

This paper provides an analysis of the different channels through which trade openness affects firms' prospects for survival. Import competition always squeezes out domestic firms, but export openness has ambiguous effects which depend on the relative strength of increased profit opportunities due to export expansion and factor market repercussions. Furthermore, industries with a high degree of product differentiation react differently to import and export openness than do industries comprising mainly homogeneous products. As a result, trade exposure always increases firm failure, but this effect is mainly driven by the import- "push" in industries where product differentiation is high, whereas it is driven by the export- "pull" in industries where product differentiation is limited.

Though both aspects of trade openness affect firm failure, the implied labor market repercussions 
are quite different. In the case of import competition, the displacement of workers due to firm exit is not counterbalanced by an equal increase in labor demand at other firms. For export openness, on the contrary, firm selection is indeed a consequence of such increases in the demand for a limited pool of workers. As a result, adjustment costs are lower in the latter case and disentangling both effects has important implications for the public debate. Linking the wage dynamics at exporting firms described in Amiti \& Davis (2011) to the industry dynamics highlighted in this paper therefore constitutes a promising avenue for future research.

\section{References}

Amiti, M., \& Davis, D. R. (2011). Trade, firms and wages: Theory and evidence. Review of Economic Studies, 78(4).

Angrist, J. D., \& Pischke, J.-S. (2009). Mostly Harmless Econometrics: An Empiricist's Companion. Princeton University Press.

Baggs, J. (2005). Firm survival and exit in response to trade liberalization. Canadian Journal of Economics, 38(4), 1364-1383.

Baldwin, J., \& Yan, B. (2011). The death of Canadian manufacturing plants: heterogeneous responses to changes in tariffs and real exchange rates. Review of World Economics (Weltwirtschaftliches Archiv), $147(1), 131-167$.

Bernard, A. B., \& Jensen, J. B. (2007). Firm structure, multinationals, and manufacturing plant deaths. The Review of Economics and Statistics, 89(2), 193-204.

Bernard, A. B., Jensen, J. B., Redding, S. J., \& Schott, P. K. (2007). Firms in international trade. Journal of Economic Perspectives, 21(3), 105-130.

Bernard, A. B., Jensen, J. B., \& Schott, P. K. (2006). Survival of the best fit: Exposure to lowwage countries and the (uneven) growth of U.S. manufacturing plants. Journal of International Economics, 68(1), 219-237.

Boone, J. (2008). Competition: Theoretical parameterizations and empirical measures. Journal of Institutional and Theoretical Economics, 164(4), 587-611.

Brander, J., \& Krugman, P. (1983). A 'reciprocal dumping' model of international trade. Journal of International Economics, 15(3-4), 313-321.

Broda, C., \& Weinstein, D. E. (2006). Globalization and the gains from variety. The Quarterly Journal of Economics, 121(2), 541-585.

Chaney, T. (2008). Distorted gravity: The intensive and extensive margins of international trade.

The American Economic Review, 98, 1707-1721(15). 
Chen, N., Imbs, J., \& Scott, A. (2009). The dynamics of trade and competition. Journal of International Economics, $77(1), 50-62$.

Colantone, I., \& Sleuwaegen, L. (2010). International trade, exit and entry: A cross-country and industry analysis. Journal of International Business Studies, 41(7), 1240-1257.

Coucke, K., \& Sleuwaegen, L. (2008). Offshoring as a survival strategy: evidence from manufacturing firms in Belgium. Journal of International Business Studies, 39(8), 1261-1277.

Del Gatto, M., Ottaviano, G. I. P., \& Pagnini, M. (2008). Openness to trade and industry cost dispersion: Evidence from a panel of Italian firms. Journal of Regional Science, 48(1), 97-129.

Emami Namini, J., Facchini, G., \& Lopez, R. (2011). Export growth and factor market competition: theory and evidence. CEPR Discussion Papers 8256.

Ericson, R., \& Pakes, A. (1995). Markov-perfect industry dynamics: A framework for empirical work. The Review of Economic Studies, 62(1), 53-82.

Eriksson, T., Smeets, V., \& Warzynski, F. (2009). Small open economy firms in international trade: Evidence from Danish transactions-level data. Danish Economic Journal (Nationaløkonomisk Tidsskrift), 147, 175-194.

Felbermayr, G. J., \& Spiegel, G. (2012). A simple theory of trade, finance, and firm dynamics. CESifo Working Paper Series 3873.

Foster, L., Haltiwanger, J., \& Syverson, C. (2008). Reallocation, firm turnover, and efficiency: Selection on productivity or profitability? American Economic Review, 98(1), 394-425.

Greenaway, D., Gullstrand, J., \& Kneller, R. (2008). Surviving globalisation. Journal of International Economics, $74(2), 264-277$.

Grubel, H., \& Lloyd, P. (1975). Intra-industry trade. MacMillan: London.

Gu, W., Sawchuk, G., \& Rennison, L. (2003). The effect of tariff reductions on firm size and firm turnover in Canadian manufacturing. Review of World Economics (Weltwirtschaftliches Archiv), $139(3), 440-459$.

Guth, L. A. (1971). Advertising and market structure revisited. The Journal of Industrial Economics, $19(2), 179-198$.

Harris, R. I., \& Li, Q. C. (2010). Export-market dynamics and the probability of firm closure: Evidence for the UK. Scottish Journal of Political Economy, 57(2), 145-168.

Head, K., \& Ries, J. (1999). Rationalization effects of tariff reductions. Journal of International Economics, 47(2), $295-320$.

Hopenhayn, H. A. (1992). Entry, exit, and firm dynamics in long run equilibrium. Econometrica, $60(5)$, 1127-50. 
Krishna, P., Poole, J. P., \& Senses, M. Z. (2011). Wage effects of trade reform with endogenous worker mobility. NBER Working Papers 17256.

Krugman, P. R. (1979). Increasing returns, monopolistic competition, and international trade. Journal of International Economics, 9(4), 469-479.

Melitz, M. J. (2003). The impact of trade on intra-industry reallocations and aggregate industry productivity. Econometrica, 71(6), 1695-1725.

Melitz, M. J., \& Ottaviano, G. I. P. (2008). Market size, trade, and productivity. Review of Economic Studies, 75(1), 295-316.

Mullahy, J. (1997). Instrumental-variable estimation of count data models: Applications to models of cigarette smoking behavior. The Review of Economics and Statistics, 79(4), 586-593.

Mullahy, J. (1999). Interaction effects and difference-in-difference estimation in loglinear models. NBER Technical Working Papers 0245.

Pflüger, M. P., \& Russek, S. (2011). Business conditions and default risks across countries. IZA Discussion Papers 5541.

Pirotte, A. (1999). Convergence of the static estimation toward the long run effects of dynamic panel data models. Economics Letters, 63(2), 151-158.

Rauch, J. E. (1999). Networks versus markets in international trade. Journal of International Economics, 48(1), 7-35.

Roberts, M. J., \& Tybout, J. R. (1991). Size rationalization and trade exposure in developing countries. In Empirical Studies of Commercial Policy, NBER Chapters, (pp. 169-200).

Santos Silva, J. M. C., \& Tenreyro, S. (2006). The log of gravity. The Review of Economics and Statistics, 88(4), 641-658.

Schröder, P. J., \& Sørensen, A. (2012). Firm exit, technological progress and trade. European Economic Review, 56(3), 579-591.

Shapiro, D., \& Khemani, R. S. (1987). The determinants of entry and exit reconsidered. International Journal of Industrial Organization, 5(1), 15-26.

Siegfried, J. J., \& Evans, L. B. (1994). Empirical studies of entry and exit: A survey of the evidence. Review of Industrial Organization, 9, 121-155.

Sutton, J. (2007). Market structure: Theory and evidence. In M. Armstrong, \& R. Porter (Eds.) Handbook of Industrial Organization, vol. 3, (pp. 2301 - 2368).

Syverson, C. (2004). Product substitutability and productivity dispersion. The Review of Economics and Statistics, 86(2), 534-550.

Trefler, D. (2004). The long and short of the Canada-U.S. free trade agreement. American Economic 
Review, 94(4), 870-895.

Wooldridge, J. M. (2001). Econometric Analysis of Cross Section and Panel Data. The MIT Press.

\section{A Appendix}

Table A.1: Sector and industry classification ${ }^{\mathrm{a}}$

\begin{tabular}{|c|c|c|c|}
\hline \multirow[b]{2}{*}{ Sector (53-grouping) } & \multirow[b]{2}{*}{ Industry (111-grouping) } & \multicolumn{2}{|c|}{ Product differentiation } \\
\hline & & GL & Rauch \\
\hline \multirow{4}{*}{ Food, beverage and tobacco } & Production etc. of meat and meat products & 0.242 & 0.084 \\
\hline & Bakers shops & 0.732 & 1.000 \\
\hline & Mfr. of other food products & 0.485 & 0.391 \\
\hline & Mfr. of beverages & 0.314 & 0.098 \\
\hline \multirow{3}{*}{ Textiles and leather } & Mfr. of textiles & 0.595 & 0.776 \\
\hline & Mfr. of wearing apparel & 0.833 & 1.000 \\
\hline & Mfr. of leather and footwear & 0.670 & 0.847 \\
\hline Wood & Mfr. of wood and wood products & 0.386 & 0.556 \\
\hline \multirow{4}{*}{ Paper and printing } & Mfr. of pulp, paper and paper products & 0.421 & 0.152 \\
\hline & Publishing of newspapers & & 1.000 \\
\hline & Publishing activities, excluding newspapers & 0.735 & 0.630 \\
\hline & Printing activities & 0.659 & 0.500 \\
\hline \multirow{3}{*}{ Chemicals } & Mfr. of chemical raw meterials & 0.287 & 0.027 \\
\hline & Mfr. of paints and soap & 0.595 & 0.512 \\
\hline & Mfr. of pharmaceuticals & 0.420 & 0.495 \\
\hline Rubber & Mfr. of rubber and plastic products & 0.592 & 0.485 \\
\hline \multirow{2}{*}{ Stone, clay and glass } & Mfr. of glass and ceramic goods & 0.429 & 0.765 \\
\hline & Mfr. of tiles bricks, cement and concrete & 0.390 & 0.844 \\
\hline \multirow{3}{*}{ Basic metals } & Mfr. of basic metals & 0.390 & 0.171 \\
\hline & Mfr. of building materials of metal & 0.641 & 0.310 \\
\hline & Mfr. of various metal products & 0.616 & 0.925 \\
\hline \multirow{5}{*}{ Mechanical engineering } & Mfr. of marine engines, compressors & 0.483 & 0.731 \\
\hline & Mfr. of ovens and cold-storage plants & 0.522 & 0.924 \\
\hline & Mfr. of agricultural machinery & 0.522 & 1.000 \\
\hline & Mfr. of machinery for industries & 0.486 & 0.869 \\
\hline & Mfr. of domestic appliances & 0.512 & 1.000 \\
\hline \multirow{2}{*}{ Electronics } & Mfr. of computers and electric motors & 0.516 & 0.844 \\
\hline & Mfr. of medical equipment optical instruments & 0.471 & 0.841 \\
\hline \multirow{2}{*}{ Transport equipment } & Building of ships and boats & 0.561 & 0.870 \\
\hline & Mfr. of transport equipment, excl. ships & 0.444 & 0.563 \\
\hline \multirow{2}{*}{ Furniture and other } & Mfr. of furniture & 0.531 & 0.933 \\
\hline & Mfr. of toys and jewelery & 0.615 & 0.878 \\
\hline
\end{tabular}

${ }^{a}$ Industries not included in the sample: Mfr. of tobacco products, Mfr. of dairy products, Mfr. of refined petroleum products, Mfr. of chemical raw materials, Mfr. of radio and communication equipment. 


\section{Economics Working Papers}

2013-07: John Kennes and John Knowles: Can technological change account for the sexual revolution?

2013-08: Christian Bjørnskov: Types of Foreign Aid

2013-09: John Kennes and Daniel le Maire: Job Heterogeneity and Coordination Frictions

2013-10: Peter Arendorf Bache and Anders Laugesen: Monotone Comparative Statics for the Industry Composition under Monopolistic Competition

2013-11: $\quad$ Anders Frederiksen and Jesper Rosenberg Hansen: Trends in Sector Switching: Evidence from Employer-Employee Data

2013-12: Mongoljin Batsaikhan and Norovsambuu Tumennasan: Price-Matching leads to the Cournot Outcome

2013-13: Sylvanus Kwaku Afesorgbor: Revisiting the Effectiveness of African Economic Integration. A Meta-Analytic Review and Comparative Estimation Methods

2013-14: Peter Arendorf Bache and Anders Laugesen: Trade Liberalisation and Vertical Integration

2013-15: Kaleb Girma Abreha, Valérie Smeets and Frédéric Warzynski: Coping with the Crisis: Recent Evolution in Danish Firms' - International Trade Involvement, 2000-2010

2013-16: Peter Arendorf Bache and Anders Laugesen: An Industry-Equilibrium Analysis of the LeChatelier Principle

2013-17: $\quad$ Anna Piil Damm and Christian Dustmann: Does Growing Up in a High Crime Neighborhood Affect Youth Criminal Behavior?

2013-18: Christian Bjørnskov and Jacob Mchangama: Do Social Rights Affect Social Outcomes?

2013-19: Benoit Julien, John Kennes, and Moritz Ritter: Bidding for Clubs

2013-20: Ina Charlotte Jäkel: Import-push or Export-pull? 